\title{
Shared Syntactic Representations in Bilinguals: Evidence for the Role of Word-Order Repetition
}

\author{
Sarah Bernolet and Robert J. Hartsuiker \\ Ghent University
}

\author{
Martin J. Pickering \\ University of Edinburgh
}

\begin{abstract}
Studies on syntactic priming strongly suggest that bilinguals can store a single integrated representation of constructions that are similar in both languages (e.g., Spanish and English passives; R. J. Hartsuiker, M. J. Pickering, \& E. Veltkamp, 2004). However, they may store 2 separate representations of constructions that involve different word orders (e.g., German and English passives; H. Loebell \& K. Bock, 2003). In 5 experiments, the authors investigated within- and between-languages priming of Dutch, English, and German relative clauses. The authors found priming within Dutch (Experiment 1) and within English as a 2nd language (Experiments 2 and 4). An important finding is that priming occurred from Dutch to German (Experiment 5), which both have verb-final relative clauses; but it did not occur between Dutch and English (Experiments 3 and 4), which differ in relative-clause word order. The results suggest that word-order repetition is needed for the construction of integrated syntactic representations.
\end{abstract}

Keywords: spoken sentence production, syntactic priming, bilingualism, noun phrases, word order

The study of sentence production presents us with an interesting paradox of the language system: Although speakers have the linguistic competence to produce and comprehend an unlimited number of different sentences, they tend to repeat the same syntactic structures over and over again. Research on syntactic priming has shown that speakers tend to re-use the syntactic structures that they have recently encountered. For example, when two syntactic alternatives with roughly the same meaning are available to describe a given picture or to complete a sentence (e.g., The dog chases the cat-The cat is being chased by the dog), people are inclined to use the structure they have just read or heard as a prime (e.g., Bock, 1986, 1989; Bock \& Loebell, 1990; Branigan, Pickering, \& Cleland, 2000; Corley \& Scheepers, 2002; Hartsuiker, Kolk, \& Huiskamp, 1999; Hartsuiker \& Westenberg, 2000; Pickering \& Branigan, 1998).

This tendency to repeat syntactic structure even occurs between languages in bilinguals (Hartsuiker, Pickering, \& Veltkamp, 2004; Loebell \& Bock, 2003), suggesting that similar syntactic structures have a shared representation between different languages. However, these studies did not ask how similar syntactic structures need to be to have a shared representation. For example, an

Sarah Bernolet and Robert J. Hartsuiker, Department of Experimental Psychology, Ghent University, Ghent, Belgium; Martin J. Pickering, Department of Psychology, University of Edinburgh, Edinburgh, Scotland.

This research was supported by Fund for Scientific Research-Flanders (FWO Vlaanderen) Grant G.0427.04 and a British Academy Research Readership. We wish to thank Lennart Bernolet, Cecilia Aernaudts, Marijke Welvaert, and Wietske Van Gils for acting as confederates. We also thank Sofie Schoonbaert for her helpful suggestions regarding the design of our experiments.

Correspondence concerning this article should be addressed to Sarah Bernolet, Department of Experimental Psychology, Ghent University, Henri Dunantlaan 2, Ghent, Belgium, 9000. E-mail: sarah.bernolet @ugent.be important domain of cross-linguistic syntactic variation is word order (Greenberg, 1963). It is possible that bilingual syntactic representations abstract from the details of word order, so that otherwise similar structures that merely differ in word order across languages have a shared representation. However, it is also possible that word order is an integral part of syntactic representations, so that structures that differ in word order across languages are represented separately for each language. We use cross-linguistic syntactic priming to distinguish between these alternatives.

Studies on bilingual language processing have focused on the extent to which bilinguals have separate representations for their languages and the extent to which they use a single, integrated representation. However, the great majority of work has been concerned with the representation of words: Do bilinguals have two separate lexicons or are the words of both languages stored in one integrated lexicon? In recent years there has been much evidence for the latter option. Thus, the time-course of word processing in the target language is influenced by the activation of words in the nontarget language (Dijkstra, Van Heuven, \& Grainger, 1998; Lemhöfer \& Dijkstra, 2004; Van Hell \& Dijkstra, 2002). Likewise, effects of semantic facilitation for translation equivalents suggest that conceptual representations can be shared between two languages (Grainger \& Frenck-Mestre, 1998). Larger facilitation effects for cognates (film-film) as compared with translation equivalents (aap-monkey) seem to indicate that word forms that are identical in two languages have a shared concept (Van Hell \& De Groot, 1998) and a shared or at least overlapping lexical representation (Lemhöfer, Dijkstra, \& Michel, 2004; SánchezCasas, Davis, \& Garcia-Albea, 1992). Analogously, bilinguals could have shared representations for syntactic structures that are similar in two languages.

Syntactic representations can be investigated in syntactic priming experiments in which participants typically describe pictures of everyday objects or events (e.g., Bock, 1986). The critical pictures can be described using two (or more) syntactic structures that have 
very similar meanings (e.g., lightning strikes the church vs. the church is struck by lightning). Before the picture is presented, participants hear or read a prime sentence using a particular syntactic form. Syntactic priming occurs when participants more often describe a picture using a particular structure after they have just encountered that structure than after they have just encountered the alternative structure. Alternative methods include sentence completion (Pickering \& Branigan, 1998) and sentence recall (Potter \& Lombardi, 1998). Syntactic priming occurs for different syntactic constructions, such as transitives (Bock, 1986; Hartsuiker \& Kolk, 1998a), datives (Bock, 1986; Hartsuiker \& Kolk, 1998b; Pickering \& Branigan, 1998; Pickering, Branigan, \& McLean, 2002), noun phrases (Cleland \& Pickering, 2003), and relative clauses (Ferreira, 2003). Most studies have used English, but the effects have also been found in Dutch (Hartsuiker \& Kolk, 1998a, 1998b; Hartsuiker et al., 1999; Hartsuiker \& Westenberg, 2000) and in German (Scheepers, 2003).

Syntactic priming occurs not only during sentence production but also during comprehension: The repetition of syntactic structure facilitates the comprehension of sentences (Arai, Van Gompel, \& Scheepers, 2007; Branigan, Pickering, \& McLean, 2005; Noppeney \& Price, 2004). Branigan et al. (2000) found syntactic priming between comprehension and production in dialogue. Such priming appeared to be particularly strong (though there has been no direct comparison with monologue). A possible explanation is that syntactic alignment during conversation facilitates mutual understanding (Pickering \& Garrod, 2004). Furthermore, Pickering and Branigan (1998) found that syntactic priming is enhanced by lexical repetition: Priming effects for dative sentences were stronger when the head verb was repeated across prime and target sentences than when a different verb was used. However, syntactic priming also occurred in the absence of lexical repetition between prime and target structures, as in many other studies (e.g., Bock, 1986). This indicates that the effects are not just due to lexical repetition: Priming seems to operate at a fairly abstract level of representation.

Monolingual studies on syntactic priming have suggested that word order can be a determinant of the occurrence of syntactic priming (Hartsuiker et al., 1999; Hartsuiker \& Westenberg, 2000; Pickering et al., 2002). Hartsuiker et al. (1999) found that word order by itself can be primed. In the experiment, the syntactic alternatives that were used as primes were identical with respect to functional and hierarchical relations between constituents, and only the word order differed $(1 \mathrm{a}-1 \mathrm{~b})$.

1a. Op de tafel ligt een bal

[On the table lies a ball]

1b. Een bal ligt op de tafel

[A ball lies on the table]

Their experiment showed that word order did persist: After a prime sentence with a given word order, speakers were more likely to re-use that specific word order than to use the alternative order. Although these data suggest that word order can be primed, an alternative explanation attributes these effects to conceptual priming (the topic-comment structure differs between $1 \mathrm{a}$ and $1 \mathrm{~b}$ ). However, Hartsuiker and Westenberg (2000) found persistence of the order of auxiliary and participle in Dutch ( $2 a$ and $2 b)$.

2a. Ik kon er niet door omdat de weg was geblokkeerd

[I couldn't pass through because the road was blocked]

2b. Ik kon er niet door omdat de weg geblokkeerd was
[I couldn't pass through because the road blocked was]

As auxiliaries are function words without any intrinsic meaning, they cannot cause conceptual priming. On the basis of these results, Hartsuiker et al. (1999) and Hartsuiker and Westenberg (2000) concluded that constituent structure is underspecified for word order. Following Kempen and Hoenkamp (1987) and De Smedt (1990), they have assumed that after a constituent structure is constructed, a subsequent linearization process imposes word order on that structure. This two-stage model of syntax production allows for incremental processing: As soon as a unit is constructed at the constituent structure level, it can be transferred to the linearization process. Constituents that are constructed early (because they are highly accessible) are placed as early as possible in the sentence. This minimizes the need to buffer constituents and hence facilitates sentence formulation (cf. Ferreira, 1996).

The two-stage model was challenged, however, by Pickering et al. (2002). They tested priming with English "shifted" datives, in which the prepositional phrase preceded the noun phrase (3a).

3a. The captain gave to the old sailor the spare lifejacket

$3 \mathrm{~b}$. The captain gave the spare lifejacket to the old sailor

Although shifted datives and prepositional object (PO) datives (3b) arguably constitute different forms of the same construction, there was no priming from shifted datives to PO datives, suggesting that these structures do not share a representation of their common constituent structure that is not yet specified for word order. Pickering et al. (2002) therefore concluded that constituent structure is formulated in one stage: Presyntactic representations are mapped onto representations that are fully specified syntactically. According to this view, word order is part of constituent structure.

\section{Syntactic Priming Across Languages}

A few recent studies have examined syntactic priming across languages. Because syntactic constructions are often quite similar in different languages, it is important to investigate how such similarity affects the representation of syntactic structure in bilinguals. Is the syntax of each language stored separately (separatesyntax account) or is syntactic information shared between the languages (shared-syntax account)? According to the sharedsyntax account, people who know English, Dutch, and French have only one representation for the structure of the English question "Is he ill?" and the Dutch translation of that question "Is hij ziek?", as these questions are structurally similar in the two languages. In contrast, a French translation of that question, "Est-ce qu'il est malade?", probably does not share a representation with either the Dutch or the English sentence, as this sentence is formed by applying different syntactic rules (e.g., to introduce the interrogative particle est-ce que and to capture the order of subject and auxiliary). So the shared-syntax account claims that representations are shared whenever possible. But according to the separatesyntax account, all three sentence structures are represented separately, irrespective of the formal similarity between the English and the Dutch sentences.

As stated above, the existence of shared representations for syntactic structures of different languages can be studied with syntactic priming. For example, if the same syntactic representation is activated to produce English and Dutch passive sentences (The boy is being hit by a baseball and De jongen wordt getroffen 
door een honkbal), then it should be possible to prime the use of Dutch passive sentences by presenting English passives and vice versa. The occurrence of syntactic priming across languages would therefore provide evidence for the shared-syntax account.

Loebell and Bock (2003) presented some evidence for this account. They found cross-linguistic syntactic priming between German (native language, henceforth L1) and English (a later acquired second language, henceforth L2) in a picture description task (L1 $\rightarrow$ L2 and L2 $\rightarrow$ L1). They used datives (PO and double-object [DO] datives) and transitives (actives and passives). The participants first repeated a prime sentence in either their first or their second language and then described a picture in the other language. They found that German datives $(4 a, 5 a)$ were primed by English datives (4b, 5b) and vice versa. For transitives (6a, 6b, 7a, $7 b$ ), however, no cross-linguistic priming was found.

4a. Der kleine Junge schrieb seinem Brieffreund einen Brief (DO-German)

[The little boy wrote his pen pal a letter]

4b. A boy is giving a girl a present (DO-English)

5a. Der kleine Junge schrieb einen Brief an seinen Brieffreund (PO-German)

[The little boy wrote a letter to his pen pal]

5b. A boy is giving a present to a girl (PO-English)

6a. Der chemische Abfall vergiftete den Fluss (Active-German)

[The chemical waste poisoned the river]

6b. The fire hydrant is squirting a firefighter (Active-English)

7a. Der Fluss wurde von dem chemischen Abfall vergiftet (Passive-German: verb-final)

[Literally: The river was by the chemical waste poisoned]

$7 \mathrm{~b}$. The firefighter is being squirted by a fire hydrant (PassiveEnglish: by-phrase final)

Loebell and Bock (2003) argued that the absence of crosslinguistic priming for passives could be explained in terms of the word-order differences between English and German passives. In English, the by-phrase is placed at the end of the sentence, whereas in German, the past participle comes at the end of the sentence and is preceded by the by-phrase (cf. 7a and 7b). However, they repeated the experiment with German primes and targets. In this within-language experiment, there was no significant priming effect with transitives either. Thus, the absence of cross-linguistic priming may have resulted from an absence of syntactic priming with German transitives in general.

Hartsuiker et al. (2004) did find significant cross-linguistic priming for transitive sentences. They had Spanish-English bilinguals describe cards to each other in a dialogue game (cf. Branigan et al., 2000). Participants first heard a prime description in their L1 (Spanish) and then had to describe the subsequent picture using their L2 (English). The experiment showed cross-linguistic priming for passive sentences: Spanish-English bilinguals tended to produce English passive sentences more often following a Spanish passive than following a Spanish active or an intransitive sentence. In Spanish and English, however, passive sentences have an identical word order (see 8).

$8 \mathrm{a}$. The truck is chased by the taxi

8b. El camión es perseguido por el taxi

Hence, cross-linguistic priming of transitives can occur when the word order of the sentences is the same.

Cross-linguistic priming (L1 $\rightarrow$ L2 and L2 $\rightarrow$ L1) also occurs for dative sentences in Spanish-English bilinguals (Meijer \& Fox
Tree, 2003) and in Dutch-English bilinguals (Schoonbaert, Hartsuiker, \& Pickering, 2007). Meijer and Fox Tree (2003) used a sentence recall task (Potter \& Lombardi, 1998) and found that English dative sentences with a DO structure are more often falsely remembered as datives with a prepositional object after Spanish datives containing a prepositional object than after Spanish primes that contain no prepositional object. However, their task was very demanding: Many participants could not remember more than half of the target sentences correctly. This resulted in a great loss of data, as these participants were excluded from the analyses. Moreover, the items in this study were not rotated across conditions, so there is a possibility that these priming effects were due to item idiosyncrasies.

Using spoken dialogue, Schoonbaert et al. (2007) found priming in L1 (Dutch), in L2 (English), and between L1 and L2 (in both directions) for dative sentences. Within-language priming was enhanced when the verb was repeated between prime and target (as in Branigan et al., 2000; Corley \& Scheepers, 2002; Cleland \& Pickering, 2006; Pickering \& Branigan, 1998) in L1 and L2. Cross-linguistic priming was enhanced when prime and target verbs were translation equivalents but only when priming from L1 to $\mathrm{L} 2$.

The cross-linguistic syntactic priming effects discussed above could in theory be due to lexical priming of translation-equivalent function words between languages (e.g., from por to by in Hartsuiker et al., 2004). This explanation is unlikely because there is no evidence for any effect of function word repetition on withinlanguage syntactic priming (Bock, 1989; Fox Tree \& Meijer, 1999). Moreover, Desmet and Declercq (2006) showed that relative clause attachments (e.g., Someone shot the servant of the actress who was on the balcony, where the servant or the actress can be on the balcony) can be primed from Dutch to English in Dutch-English bilinguals. As the same words are used for both attachments, these results show that abstract structure can be primed.

In addition, cross-linguistic priming effects can be lexically triggered. Salamoura and Williams (2006) found L1 to L2 priming in a sentence completion task when participants simply read an isolated verb as the prime: More English PO datives were produced after Dutch verbs that could only take a PO dative (e.g., uitreiken [present]) than after verbs that could only take a DO dative (e.g., besparen [save]) and vice versa.

All six studies on syntactic priming across languages provide evidence for shared syntactic representations between languages. Cross-linguistic syntactic priming (L1 $\rightarrow$ L2 and L2 $\rightarrow$ L1) has been found for different syntactic structures (transitive sentences, dative sentences, relative clause attachment) and between different pairs of languages (German-English, Spanish-English, and Dutch-English). The only case in which priming did not occur, and hence there is no evidence for shared representations, is passive sentences in German-English bilinguals (Loebell \& Bock, 2003).

\section{The Effect of Word Order on Cross-Linguistic Priming of} Syntactic Structure

As the results of several within-language priming studies suggest that word order influences syntactic priming, the most obvious explanation for the absence of cross-linguistic priming between 
German and English passives (Loebell \& Bock, 2003) is differences in word order. In our study, we focused on the adjectival modification of nouns. In English, a noun can be modified by an adjective in two ways: Either the adjective is placed before the noun (9a, henceforth $A N$-structure) or the noun is followed by a relative clause containing the adjective ( $9 \mathrm{~b}$, henceforth $R C$ structure)

9a. the red shark

$9 \mathrm{~b}$. the shark that is red

Cleland and Pickering (2003) showed priming of syntactic structure of noun phrases (i.e., AN- vs. RC-structures) in English. More RC-structures were produced following an RC-structure than following an AN-structure. Furthermore, just as with dative sentences, the priming effect for noun phrases was "boosted" by lexical repetition: Though priming was obtained when prime and target descriptions contained different head nouns, the effect was larger when they contained the same head noun.

In this study, we first investigate such priming effects in Dutch as L1 (Experiment 1) and in English as L2 (Experiment 2). Our main question is, however, whether there is cross-linguistic priming for these types of noun phrases. Both the AN-structures and the RC-structures are comparable in Dutch and in English. However, whereas the AN-structures have identical word order (see 10a10b), the RC-structures have a different word order in Dutch and English (see 11a-11b). In German, both the AN-structures and the $\mathrm{RC}$-structures have a word order that is identical to that of the Dutch AN- and RC-structures (see 10c and 11c).

10a. the red shark (AN-structure, English)

10b. de rode haai (AN-structure, Dutch)

10c. der rote Hai (AN-structure, German)

11a. the shark that is red (RC-structure, English)

11b. de haai die rood is (RC-structure, Dutch)

11c. der Hai der rot ist (RC-structure, German)

In Dutch and in German, the adjective (rood or rot) is placed between the relative pronoun and the verb of the relative clause (see 11b and 11c), whereas in English, the adjective (red) is placed at the end of the relative clause (see 11a). The order of the adjective and the verb of the relative clause could influence the occurrence of cross-linguistic priming. If word order equivalence is necessary for syntax to be shared between languages, then we should not find priming of RC-structures between Dutch and English. However, we should find priming of RC-structures between Dutch and German. If word order equivalence is not necessary for syntax to be shared between languages, we should obtain priming of RC-structures between Dutch and English. In addition, we might find priming of AN-structures between Dutch and English and between Dutch and German.

If word order equivalence is indeed necessary for crosslinguistic priming, this would provide evidence against two-stage models of bilingual sentence production. If syntactic structures are constructed in two stages, there might be a common representation for RC-structures, irrespective of word order. Hence, crosslinguistic priming of these structures could be expected to occur not only between Dutch and German but between Dutch and English as well (to a lesser extent, as between Dutch and English only the common representation could be primed, whereas between Dutch and German both the common representation and the word-order specific representation could cause priming). According to the single-stage account, structures that have different word orders cannot be shared. Accordingly, an absence of crosslinguistic priming between Dutch and English RC-structures is predicted. We assume that the AN-structure is so greatly favored that we expect most-if not all-priming to be driven by the $\mathrm{RC}$-structures (see the introduction of Experiments $3 \mathrm{a}$ and $3 \mathrm{~b}$ for a more detailed discussion). Because the RC-structures would be driving the effects, the predictions depend on whether the $\mathrm{RC}$ is similar or different across languages.

We investigated cross-linguistic priming of noun phrases in four experiments. In Experiment 3a, we studied priming from Dutch (L1) to English (L2), and in Experiment 3b, we studied priming from English (L2) to Dutch (L1). In Experiment 4, we compared priming within English (L2) and priming from Dutch (L1) to English (L2) in a within-participants design. In Experiment 5, we studied priming from Dutch (L1) to German (L2). However, first we examined priming for noun phrases in two within-language experiments, conducted in Dutch (L1) and English (L2). All experiments used a computerized version of the "dialogue game" (similar to Schoonbaert et al., 2007). The prime sentences were produced by a confederate who pretended to be a participant in the experiment. The confederate and the participant took turns to describe pictures that were presented on a computer screen (with the confederate and the participant each looking at his or her own computer screen so that the participant could not see that the confederate saw prime sentences instead of pictures).

\section{Experiment 1: Dutch (L1) to Dutch (L1) Priming}

This experiment tested whether noun-phrase structure can be primed in Dutch. The design of this experiment is based on Experiment 1 of Cleland and Pickering (2003) but differs in that we used pictures of everyday objects rather than geometrical figures and that we presented the stimuli on a computer screen rather than on cards.

\section{Method}

Participants. Thirty-two 1st-year psychology students at Ghent University (22 women and 10 men) participated in exchange for course credit. All participants were native speakers of Dutch and had normal or corrected-to-normal vision. A female doctoral student (with Dutch as L1) acted as the confederate.

Materials. Three sets of 48 pictures were constructed for the participants: one response set and two description sets. Each picture displayed a $4 \times 4$ grid of objects so that each row contained four versions of a particular object (e.g., a baby), each of a different color (red, yellow, green, or blue); within each column, the color of the objects was the same (see Figure 1). The four objects were always a target object, a semantically and phonologically unrelated control object, and two filler objects. Next to each of the 16 objects a letter from "a" to "p" was printed. Each of the 24 possible orders of objects (target object, control object, and two filler objects) and each of the 24 possible orders of the colors of the columns occurred equally often. The pictures in both the response set and the description sets were identical, apart from the fact that in the description sets either the prime object or the control object was framed in a black rectangle. In addition to the 48 critical pictures, there were four filler pictures in the three sets, each depicting four objects that appeared as filler objects in the critical pictures. 

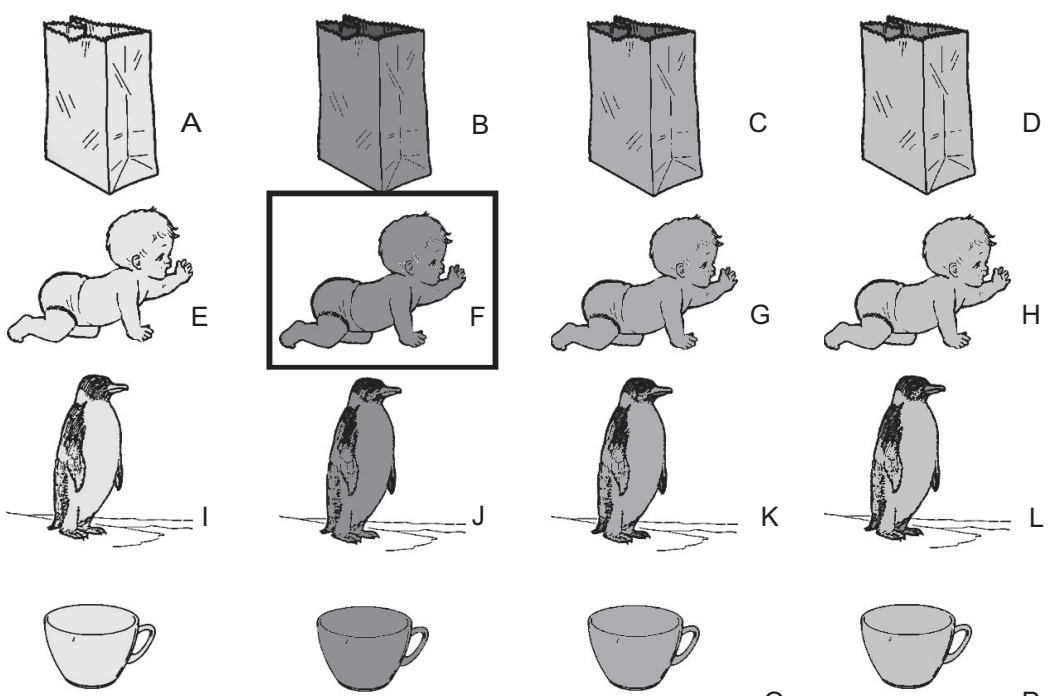

$\mathrm{N}$
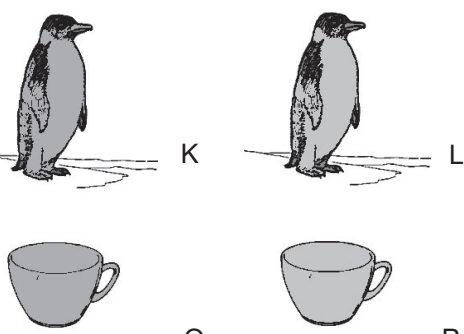

$P$

Figure 1. Example of a target picture. The target object is framed in a black rectangle.

The confederate's description and response sets did not contain pictures but instead contained phrases. The confederate's description set contained descriptions for the objects in each of the pictures in the participant's response set. These prime descriptions could have an AN-structure (12a) or an RC-structure (12b).

12a. de rode baby

[the red baby]

$12 \mathrm{~b}$. de baby die rood is

[Literally: the baby that red is (i.e., the baby that is red)]

An item was defined as the pairing of a confederate's prime sentence with the description of a target picture. In the same-object conditions, the noun that was used to describe the upcoming target object (the target noun) was the same noun as the one that was used in the prime description (the prime noun); in this case, baby. In the different-object conditions, the unrelated control object (penguin) was selected as target picture. In this case, the prime and target nouns were semantically and phonologically unrelated. The prime nouns and their unrelated controls had the same number of syllables and were matched for prosody. In Experiments 1-4, half of the prime nouns were Dutch-English cognates with an identical orthographic form (e.g., baby-baby), and half were translation equivalents with an unrelated orthography in Dutch and English (e.g., ananas-pineapple). In Experiment 5, 26 of the 48 target items were Dutch-German cognates. However, no experiment revealed any effects of the cognate status of the items that were used. Therefore, this factor was removed from the analyses of all experiments. All prime and target nouns had common (non-neuter) gender so that for all nouns the same determiner ( $d e[t h e]$ ) and the same relative pronoun (die [that]) could be used. The colors of prime and target objects were always different (see Appendix A for a list of items).

Four counterbalanced pseudorandom lists were constructed so that each target object was preceded by the same object in two lists (same-object conditions) and by a different object in the two other lists (different-object conditions). Both in the same-object and the different-object conditions the target picture was preceded by an
AN-description in two lists and by an RC-description in the two other lists. Within each list, there were $12 \mathrm{AN}$ - and $12 \mathrm{RC}$-prime sentences in the same-object condition and $12 \mathrm{AN}$ - and $12 \mathrm{RC}$ prime sentences in the different-object condition. For each of the four lists, the trials were presented in the same pseudorandom order. At the beginning of each list, four filler trials were presented, one in each prime condition. The primes for these filler trials were counterbalanced across the four lists. Each participant was presented with one of these four lists.

Procedure. Though participants were tested individually, they were under the misapprehension that they were tested in pairs because the confederate pretended to be the 2nd participant in the experiment. Both the participant and the confederate were seated in front of a personal computer (PC), and they were told that they would be playing a dialogue game: They would have to describe pictures to each other and verify each other's descriptions (see Figure 2). The confederate and the participant were seated opposite each other, with the PCs between them. Neither of them could see what appeared on the opposite screen. First, they were familiarized with the material in a study session, in which each of the 192 objects (48 prime objects, 48 control objects, and 96 filler objects) was presented together with its name. The participant and the confederate were instructed to look at the pictures and to memorize the corresponding names. After that, the participant's first response picture was shown to explain how the objects were arranged on the screen and how the participants were supposed to respond. The use of either AN- or RC-structures was avoided in the instructions. Instead, both dialogue partners were told that they would have to mention the name of the object that was depicted and its color, because every object could have four different colors They were informed that their speech would be recorded on minidisk. The program for the participants always showed a response picture as first picture. In this way, we ensured that the confederate would always be able to take the first turn.

The participant and the confederate performed phrase/picture matching while their dialogue partner was speaking. The partici- 

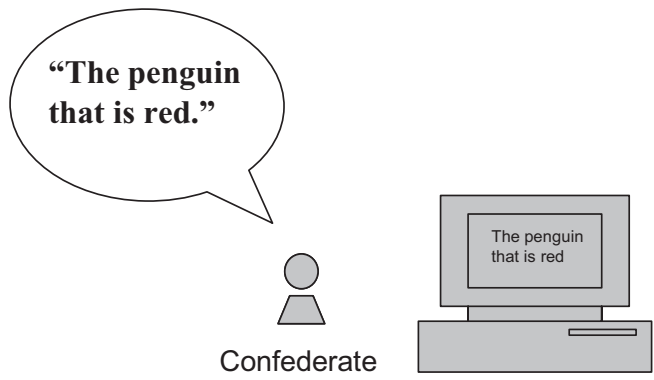

\section{PRIME}

TARGET

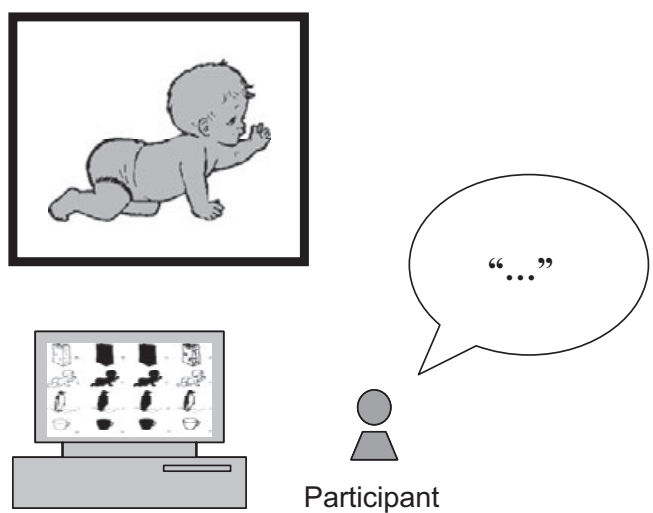

Figure 2. Computerized version of the dialogue game (the target object is framed in a black rectangle). During the experiment, the participants were seated opposite to each other, so they could not see what appeared on the computer screen of their dialogue partner.

pants responded to the confederate's prime descriptions by typing the letter printed next to the object that was described to them. For each description of the participants, a combination of a color and a noun was presented to the confederate. The confederate had to tap the "y" key if this combination matched the participant's description. If either the color or the object was different, the confederate had to type the first letter of the word (the adjective or the noun) that did not match the participant's description. If both the color and the object were different, the confederate had to tap the " $n$ " key. We made the confederate's filler task rather complicated to avoid routine in the confederate's responses, because consistently fast responses by the confederate might arouse suspicion.

The sequence of events during the experiment was as follows:

1. A picture appeared on the screen of the participant's PC (see Figure 1, but without the black rectangle). This picture was necessary for the verification task.

2. The confederate read the prime description from the screen of the PC.

3. The participant responded to the prime description by typing the letter that appeared next to the object that matched the description. When any of the keys on the keyboard was pressed, the response picture automatically changed into a description picture. At the same time, a beep notified the confederate that the participant had responded.

4. At the sound of the beep, the confederate had to press " 3 " to change the prime sentence into a noun phrase. This noun phrase was necessary for the confederate's verification task.

5. The participant produced a description for the target object in the description picture that was framed by a rectangle (see Figure 1).

6. The confederate responded to the participant's description by pressing one of the keys on the keyboard. By doing this, the noun phrase was automatically replaced by the prime sentence for the next trial. At the same time, a beep notified the participant that the confederate had responded.
7. At the sound of the beep, the participant had to press " 3 " to make the response picture for the next trial appear on the screen. The experiment lasted about $15 \mathrm{~min}$.

Scoring. The responses were recorded on minidisk and were manually coded as AN- or RC-responses. A description was coded as $A N$ when the adjective preceded the noun, and no words intervened between the adjective and the noun (e.g., 12b). A description was coded as $R C$ when the adjective formed part of a relative clause following the noun, and the relative clause was introduced by die (that; e.g., 12a). Constructions with the same word order as the RC-structure that did not contain a relative pronoun (e.g., de baby in het rood [literally, the baby in the red], de baby rood [literally, the baby red]) were coded as Other. If the target noun was replaced by a synonym or a hyponym (e.g., vogel [bird] instead of eend $[$ duck]), the response was still counted as an $\mathrm{AN}$ - or an RC-response in the different object condition. In the same object condition, only responses containing an exact repetition of the head noun were counted.

\section{Results}

Of the 1,536 target responses, 4 were Other responses $(0.3 \%)$. The remaining 1,532 responses were classified either as $\mathrm{AN}$ $(1,367 ; 88.0 \%)$ or RC-responses $(165 ; 10.7 \%)$. For all four priming conditions, we then calculated the proportion of RC-responses out of all RC- and AN-responses for each participant and item (the response frequencies are reported in Table 1). These proportions were subsequently arcsine-transformed (as were the RCproportions of all other experiments reported in this article).

Analyses of variance (ANOVAs) were run on these transformed proportions with Prime Type (AN- vs. RC-prime) as a withinparticipant and within-item factor and Object Repetition (same vs. different object) as a within-participant and between-items factor. More RC-responses were produced after RC-primes (19.9\%) than after AN-primes (1.6\%). This $18.3 \%$ effect of Prime Type was significant, $F_{1}(1,31)=22.96, M S E=6.07, p<.001 ; F_{2}(1,94)=$ 
Table 1

Response Frequencies of Experiment $1(L 1 \rightarrow L 1)$, Experiment 2 (L2 $\rightarrow$ L2), Experiment $3 a(L 2$ $\rightarrow$ L1), and Experiment $3 b(L 1 \rightarrow L 2)$

\begin{tabular}{|c|c|c|c|c|c|c|c|}
\hline \multirow[b]{3}{*}{ Experiment } & \multirow[b]{3}{*}{ Prime type } & \multicolumn{6}{|c|}{ Object type } \\
\hline & & \multicolumn{3}{|c|}{ Repeated object } & \multicolumn{3}{|c|}{ Different object } \\
\hline & & AN & $\mathrm{RC}$ & Other & AN & $\mathrm{RC}$ & Other \\
\hline \multirow[t]{2}{*}{ 1: $\mathrm{L} 1$ to $\mathrm{L} 1$} & AN & 378 & 6 & 0 & 378 & 6 & 0 \\
\hline & $\mathrm{RC}$ & 290 & 90 & 4 & 321 & 63 & 0 \\
\hline \multirow[t]{2}{*}{ 2: $\mathrm{L} 2$ to $\mathrm{L} 2$} & AN & 381 & 1 & 2 & 339 & 4 & 41 \\
\hline & $\mathrm{RC}$ & 327 & 54 & 3 & 292 & 52 & 40 \\
\hline \multirow{2}{*}{ 3a: L2 to L1 } & AN & 186 & 0 & 6 & 186 & 0 & 6 \\
\hline & $\mathrm{RC}$ & 188 & 2 & 2 & 185 & 1 & 6 \\
\hline \multirow[t]{2}{*}{ 3b: L1 to L2 } & AN & 167 & 0 & 25 & 160 & 0 & 32 \\
\hline & $\mathrm{RC}$ & 166 & 4 & 22 & 145 & 7 & 40 \\
\hline
\end{tabular}

Note. $\quad$ L1 = native language; $\mathrm{L} 2=$ second language; $\mathrm{AN}=$ structure in which the adjective is placed before the noun; $\mathrm{RC}=$ structure in which the noun is followed by a relative clause containing the adjective.

143.36, $M S E=7.31, p<.001$. There was a main effect of Object Repetition, $F_{1}(1,31)=5.69, M S E=0.21, p<.05 ; F_{2}(1,94)=$ $6.05, M S E=0.31, p<.05$. More important, there was an interaction between Prime Type and Object Repetition, $F_{1}(1,31)=$ $6.31, M S E=0.21, p<.05 ; F_{2}(1,94)=6.05, M S E=0.31, p<$ .05 : The priming effect was larger in conditions in which the object was repeated in prime and target pictures $(21.8 \%)$ than in conditions in which the object differed (14.8\%). Separate analyses for each level of Object Repetition showed a significant effect of Prime Type for the same-object conditions, $F_{1}(1,31)=22.92$, $M S E=4.27, p<.001 ; F_{2}(1,47)=90.05, M S E=5.31, p<$ .001 ; and for the different-object conditions, $F_{1}(1,31)=18.06$, $M S E=2.01, p<.001 ; F_{2}(1,47)=53.67, M S E=2.31$, $p<.001$.

\section{Discussion}

This experiment showed a clear effect of syntactic priming and a lexical boost. Participants tended to use the syntactic structure they had recently encountered, and therefore they produced more RC-responses after RC-primes than after AN-primes. Moreover, this effect was stronger when the head noun of the prime description (the object) was repeated in the target description than when it was not. Thus, we replicated the results of Cleland and Pickering (2003; Experiment 1). The syntactic priming effects were of similar magnitude in both studies (19\% in Cleland \& Pickering's, 2003 , study vs. $18 \%$ here), but the lexical boost was larger in Cleland and Pickering's (2003) study (15\% vs. $8 \%$ here). Overall, few RC-responses were produced in our experiment. It is possible that the RC-constructions are more strongly disfavored in Dutch than English. Alternatively, the low proportion of RCconstructions in our experiment may reflect differences in procedure from Cleland and Pickering's (2003) study.

\section{Experiment 2: English (L2) to English (L2) Priming}

Experiment 1 showed that noun-phrase structure can be primed in Dutch. Before we can test for cross-linguistic priming of noun structure in Dutch-English bilinguals, we should investigate priming of noun phrases in English as a second language. Schoonbaert et al. (2007) found effects in L2 in Dutch-English bilinguals using dative structures, thereby replicating Branigan et al. (2000) for L2 English. To test whether we would obtain comparable results using noun phrases instead of dative structures, we replicated Experiment 1 using English translations of the stimuli and participants who were native Dutch speakers but bilingual in English.

\section{Method}

Participants. Thirty-two further students at Ghent University ( 25 women and 7 men) participated in exchange for course credit or payment. All of them were native speakers of Dutch and had normal or corrected-to-normal vision. They all reported to have had at least 5 years of experience with English as a second language (mean number of years of experience $=10.6$ years). A female undergraduate student (with L1 Dutch and L2 English) acted as a confederate.

Materials. The materials were identical to those in Experiment 1, except that the prime descriptions appeared in English instead of in Dutch. The noun phrases that were used for the confederate's filler task were also in English.

Procedure and design. The procedure and the design were almost identical to those of Experiment 1 . The only differences were related to the fact that in this experiment, the prime language and the target language were English instead of Dutch. Hence, in the study session that preceded the experiment, every object was presented with its English name instead of its Dutch name. The objects were named in English by the experimenter to reinforce participants' choice of words. The participants and the confederate were told that if they did not know or could not remember the English name of one of the objects during the experiment, they could use an English synonym or, if necessary, a hyponym (e.g., animal instead of lobster). If they could not think of another English word that adequately described the object in question, they could use the Dutch name of the object. Target descriptions containing Dutch nouns were counted as Other responses. In the different-object conditions, responses containing synonyms or hyponyms were counted as correct responses; in the sameobject conditions, they were counted as Others. After this and all subsequent experiments, the participants were asked to rate their L1 (Dutch) and L2 (English) proficiency (L2 German proficiency in 
Table 2

Self-Assessed Ratings (7-Point Likert Scale Ranging From Very Bad to Very Good) of L1 and L2 Proficiency (Experiments 2, 3a, 3b, 4, and 5)

\begin{tabular}{|c|c|c|c|c|c|c|}
\hline Language & Skill & Experiment 2 & Experiment 3a & Experiment $3 b$ & Experiment 4 & Experiment 5 \\
\hline \multirow[t]{4}{*}{ L1 (Dutch) } & Writing & $5.47(1.02)$ & $5.81(1.11)$ & $5.75(1.13)$ & $6.22(0.71)$ & $5.71(0.98)$ \\
\hline & Speaking & $5.72(0.81)$ & $5.75(0.93)$ & $5.88(0.86)$ & $6.16(0.72)$ & $5.79(1.13)$ \\
\hline & Reading & $5.88(1.04)$ & $6.44(0.73)$ & $5.88(0.72)$ & $6.50(0.57)$ & $5.89(0.96)$ \\
\hline & General proficiency & $5.75(0.62)$ & $5.51(0.75)$ & $5.56(0.84)$ & $6.25(0.57)$ & $5.86(0.89)$ \\
\hline \multirow[t]{4}{*}{ L2 (English) } & Writing & $4.50(0.84)$ & $4.69(1.20)$ & $4.31(1.08)$ & $4.78(1.07)$ & \\
\hline & Speaking & $4.81(1.03)$ & $4.69(1.20)$ & $4.50(1.03)$ & $5.06(0.88)$ & \\
\hline & Reading & $5.38(1.01)$ & $5.50(0.82)$ & $5.31(1.01)$ & $5.78(0.83)$ & \\
\hline & General proficiency & $4.84(0.81)$ & $4.94(0.99)$ & $4.81(0.84)$ & $5.16(0.72)$ & \\
\hline \multirow[t]{4}{*}{ L2 (German) } & Writing & & & & & $4.54(0.79)$ \\
\hline & Speaking & & & & & $4.43(0.92)$ \\
\hline & Reading & & & & & $5.39(0.86)$ \\
\hline & General proficiency & & & & & $4.64(0.68)$ \\
\hline
\end{tabular}

Note. Standard deviations are indicated in parentheses. $\mathrm{L} 1=$ native language; $\mathrm{L} 2=$ second language.

Experiment 5) with respect to several skills (reading, writing, speaking, general proficiency) on a 7-point scale ranging from very bad to very good (see Table 2 for the means of the self-ratings of L1 and L2 proficiency for Experiments 2-5). A one-way ANOVA on the selfratings for L2 proficiency of Experiments 2-5 showed that the mean L2 proficiency did not differ significantly for any of the abovementioned language skills across experiments (all $F \mathrm{~s}<2$ ).

\section{Results}

Of the 1,536 target responses, 86 were Other responses $(5.6 \%)$. The remaining responses were classified either as $\mathrm{AN}-(1,339$; $87.2 \%)$ or RC- $(111 ; 7.2 \%)$ responses (see Table 1 for the response frequencies in all conditions). ANOVAs were run on the proportions of RC-responses with Prime Type (AN- vs. RC-prime) as a within-participant and within-item factor and Object Repetition (same vs. different object) as a within-participant and betweenitems factor. The mean proportion of RC-responses was larger after RC-primes (14.9\%) than after AN-primes (0.7\%), yielding a $14.2 \%$ effect of Prime Type, $F_{1}(1,31)=17.42, M S E=3.54, p<$ $.001 ; F_{2}(1,94)=44.22, M S E=3.80, p<.001$. There was no main effect of Object Repetition, $F_{1}<1 ; F_{2}(1,94)=1.59$, $M S E=0.15, p>.10$, and no Prime Type $\times$ Object Repetition interaction (both $F_{\mathrm{S}}<1$ ). The effect of Prime Type was of a similar magnitude in the same-object (13.9\%) and the differentobject conditions (14.5\%). Separate analyses for each level of Object Repetition indicated that the effect of Prime Type was significant for both the same-object conditions, $F_{1}(1,31)=19.71$, $M S E=1.87, p<.001 ; F_{2}(1,47)=25.40, M S E=1.89, p<.001$; and the different-object conditions, $F_{1}(1,31)=10.65, M S E=$ $1.67, p<.005 ; F_{2}(1,47)=19.59, M S E=1.90, p<.001$.

\section{Discussion}

These results show a very clear effect of syntactic priming in L2 English: More RC-descriptions were produced after RC-primes than after AN-primes. Similar effects occurred when the head noun was repeated in prime and target descriptions and when it was not. The absence of a lexical boost means that our results differ from Cleland and Pickering's (2003) results for L1 English. Note that the RC-proportions in the current experiment were lower than in
Experiment 1 in all conditions. They were also lower than the RC-proportions in Cleland and Pickering's (2003) Experiment 1 in all conditions. The tendency to produce English RC-constructions appears to be weak for L2 participants. The low percentages of $\mathrm{RC}$-productions in this experiment could explain the lack of a lexical boost. Another possibility is that a lexical boost in L2 is less evident for repeated nouns than for repeated verbs. We return to this issue in the General Discussion section. The fact, however, that we found significant priming of noun-phrase structures in Dutch-English bilinguals in their L1 as well as in their L2, even in the absence of full lexical repetition, gives us reason to believe that we can study cross-linguistic priming of these structures in DutchEnglish bilinguals.

\section{Experiment 3: English (L2) to Dutch (L1) Priming and Dutch (L1) to English (L2) Priming}

Experiment 3 investigated cross-linguistic priming of nounphrase structure in Dutch-English bilinguals. More specifically, we wanted to know whether differences in word order can indeed influence cross-linguistic priming. Recall that Dutch and English $\mathrm{RC}$-structures have different word orders, with the adjective coming after the verb in English (the baby that is red) but before the verb in Dutch (de baby die rood is). Therefore, a syntactic priming effect in this experiment would suggest that these languages share a syntactic representation for these structures that abstracts away from word order.

The results of Experiments 1 and 2 show that the percentage of AN-structures was virtually at ceiling in primed conditions (98.4\% in Experiment 1; $99.3 \%$ in Experiment 2). The percentage of AN-responses was still very high in the RC-conditions (80.1\% in Experiment 1; 85.1\% in Experiment 2), so it seems that the AN-structure is greatly preferred to the RC-structure. As the preference for AN-structures could hardly be increased, the priming effects in Experiments 1 and 2 were caused by priming of the $\mathrm{RC}$, the structure that is less frequent. This observation is consistent with a number of studies that have shown that structures that were in general less preferred or less common were primed more than structures that were more preferred (Ferreira, 2003; Hartsuiker \& Kolk, 1998b; for a 
review, see Ferreira \& Bock, 2006). If structures need to have the identical word order before their representations can be shared across languages, no effect of syntactic priming should occur between Dutch and English noun phrases with a relative clause (RC-structures). Furthermore, if there is no crosslinguistic priming of the less frequent structure, we might not find any priming between Dutch and English noun phrases. In this experiment, we investigated priming from L2 to L1 (Experiment 3a) and from L2 to L1 (Experiment 3b).

\section{Method}

Participants. Thirty-two 1st-year Psychology students at Ghent University (1 man, 31 women) participated in exchange for course credit (16 participants in Experiment 3a, 16 participants in Experiment 3b). All participants were native speakers of Dutch and had normal or corrected-to-normal vision. They all reported to have had at least 5 years of experience with English as a second language ( $M=10$ years). A male undergraduate student (with L1 Dutch and L2 English) acted as the confederate.

Materials. The materials were identical to those in Experiments 1 and 2. In Experiment 3a, we used the English prime descriptions of Experiment 2 and the Dutch target pictures of Experiment 1; in Experiment 3b, we used the Dutch prime descriptions of Experiment 1 and the English target pictures of Experiment 2.

Procedure and design. The procedure was identical to that of Experiment 2, with the exception that the dialogue partners used different languages for their descriptions. In Experiment 3a, the confederate produced English prime descriptions, whereas the participant produced Dutch target descriptions; in Experiment 3b, the primes were produced in Dutch, and the targets had to be described in English. For this experiment, the pictures in the study session contained both the Dutch and the English names of each object. After the study session, the experimenter assigned a target language to the participant and the confederate, making it look as if these languages were randomly assigned.

\section{Results}

Experiment 3a: English (L2) $\rightarrow$ Dutch (L1). Strikingly, the participants produced only three RC-responses in the whole experiment. Of the 768 target responses, 20 were scored as Other responses $(2.6 \%)$. The remaining responses were classified either as $\mathrm{AN}-(745$ of $768 ; 97.1 \%)$ or RC- (3 of 768; $0.4 \%$ ) responses. The response frequencies are reported in Table 1. ANOVAs were run on these proportions with Prime Type (AN- vs. RC-prime) as a within-participant and within-item factor and Object Repetition (same-object vs. different-object) as a within-participant and between-items factor.

The mean proportions of RC-responses were very low in all conditions, and the $0.8 \%$ effect of Prime Type was not reliable, $F_{1}(1,15)=2.48, M S E=0.003, p>.10 ; F_{2}<1$. No other effects were significant, and none of the reported main effects interacted with the factor Prime Type.

Experiment 3b: Dutch (L1) $\rightarrow$ English (L2). The number of RC-responses in Experiment 3b (11) was only slightly higher than in Experiment 3a. Of the 768 target responses, 119 were scored as Other $(15.5 \%)$. The remaining responses were classified either as
AN- $(638$ of $768 ; 83.1 \%)$ or RC- $(11$ of $768 ; 1.4 \%)$ responses. The response frequencies are reported in Table 1 . Because of the large number of Other responses, six items were discarded from the analyses. ANOVAs were run on the proportions of RC-responses with Prime Type (AN- vs. RC-prime) as a within-participant and within-item factor and Object Repetition (same-object vs. different-object) as a within-participant and between-items factor.

Again, the proportion of RC-responses was very low in all conditions. The $3.6 \%$ difference between RC-primes and $\mathrm{AN}$ primes was not reliable, $F_{1}(1,15)=1.56, M S E=0.10, p>.10$; $F_{2}(1,88)=3.10, M S E=0.07, p<.10$. The only near significant result was a main effect of Object Repetition, $F_{1}(1,15)=3.61$, $M S E=0.03, p<.01 ; F_{2}(1,88)=3.62, M S E=0.22, p<.10$ : More RC-responses were produced in the different-object conditions than in the same-object conditions. This main effect of Object Repetition did not interact with Prime Type, $F_{1}(1,15)=1.71$, $M S E=0.01, p>.10 ; F_{2}<1$. No other effects were significant.

\section{Discussion}

In Experiments 3a (L2 $\rightarrow$ L1) and 3b (L1 $\rightarrow$ L2) only 14 of 1,536 responses were RCs, and no effect of Prime Type was obtained. Across both experiments, 26 of 32 participants (81.2\%) did not produce a single RC-description. These results strongly suggest that the syntactic priming effect that was observed in Experiments 1 and 2 does not survive in a cross-linguistic task. However, it would be premature to conclude that noun-phrase structure can only be primed within L1 Dutch and within L2 English but not across these two languages, because so far we have only presented an indirect comparison (i.e., using different participants). The purpose of Experiment 4 was to provide a direct comparison.

\section{Experiment 4: English (L2) to English (L2) and Dutch (L1) to English (L2) Priming}

In this experiment, we compared within- versus betweenlanguages priming of noun-phrase structure in a withinparticipants design. The target language was English. Participants received a within-language block of English prime descriptions and a between-languages block of Dutch prime descriptions, in one or the other order. In this way, we were able to compare withinand between-languages priming directly. We chose to investigate priming from L1 to L2 because such priming may be more likely than L2 to L1 priming. Loebell and Bock (2003) found a trend toward more syntactic priming for datives from L1 (German) to L2 (English) than vice versa. Furthermore, although Schoonbaert et al. (2007) found equivalent L1-to-L2 and L2-to-L1 priming for datives in the different verb conditions, the translation-equivalence boost only occurred from L1 to L2. Furthermore, the numerical tendency to priming in Experiment 3b (4\%) was stronger than the numerical tendency in Experiment 3a (1\%).

Additionally, Experiment 4 followed Cleland and Pickering's (2003) study more closely than Experiments 1-3: It contained an equal number of critical trials and filler trials, the factor of Object Repetition was varied within-items, and the color of prime and target objects was kept constant in the critical trials. By keeping the colors of the prime and the target objects constant, we attempted to increase the priming effects: Cleland and Pickering 
(2003) found a tendency toward stronger syntactic priming when the adjective was repeated between prime and target than when it was not.

Furthermore, we counterbalanced the order of the within- and between-languages blocks: For half of the participants, the withinlanguage block was presented first; for the other half, the betweenlanguages block was presented first. Such counterbalancing aimed to control for any "spill-over" effects from one block to the next. This is important because syntactic priming effects can be long lasting. For example, Bock and Griffin (2000) found that priming effects for English transitive and dative structures persisted over as many as 10 sentences. Additionally, Hartsuiker and Kolk (1998b) found more (transitive and dative) target responses in the experimental conditions than in a pre-experimental baseline condition, irrespective of prime type. They suggested that this difference in response frequency resulted from cumulative long-term priming of the target structures over the course of the experiment, making these structures more accessible than before the experiment. Finally, Kashak, Loney, and Borregine (2006) found that repeated exposure to a construction at the beginning of an experimental session affected subsequent priming by an immediately preceding prime. In the same way, long-term priming could influence the response patterns in our experiments.

In Experiment 4, we presented both a within-language block and a between-languages block. If the activation of different target structures is built up during an experiment, then the response patterns in the second block should be influenced by the responses in the first block. If the between-languages block is presented first, we expect virtually all responses to have the AN-structure (given the results of Experiments $3 \mathrm{a}$ and $3 \mathrm{~b}$ ). Long-term, cumulative priming of the $\mathrm{AN}$-structure could then spill over to the subsequent within-language block, reducing the frequency with which RCstructures are produced and thereby possibly reducing the priming effect caused by the RC-structures. In contrast, if the withinlanguage block is presented first, we expect some responses to have the RC-structure (given the results of Experiment 2). Priming of the RC-structure could then spill over to the subsequent between-languages block. This could lead to a higher frequency of $\mathrm{RC}$-structures than when the between-languages block is presented first. This gives the greatest chance of finding a cross-linguistic priming effect, if Dutch and English RCs do share a linguistic representation.

\section{Method}

Participants. Thirty-two students at Ghent University (23 women and 9 men) participated in exchange for a small monetary reward. All participants were native speakers of Dutch and had normal or corrected-to-normal vision. They all reported to have had at least 6 years of experience with English as a second language ( $M=13.4$ years). A female undergraduate student (with Dutch L1 and English L2) acted as the confederate.

Materials. The materials were the same as in Experiments $1-3$, except that only the response pictures from the repeated-noun condition were used. These target pictures were used in the repeated-noun conditions as well as in the different-noun conditions. The prime descriptions were altered such that each target object was preceded by a prime sentence describing a semantically unrelated control object in half of the lists. In the other half, the target object was preceded by a prime sentence describing the same object. We also changed the colors in the prime sentences so that prime and target objects had the same color. To have an equal number of critical trials and filler trials (i.e., 48), we added 44 filler picture pairs. In the filler trials, the prime object was never the same object as the target object. Furthermore, prime and target objects always had different colors in the filler trials. In this way, we had full repetition (object and color) between prime and target object for the critical trials in the same-object condition, partial repetition (only color) for the primes and targets in the differentobject condition, and no repetition for the primes and targets in the filler trials.

For this experiment, we had 16 pseudorandom lists, instead of four. The lists now consisted of two blocks: a within-language block (English primes, English target descriptions) and a betweenlanguages block (Dutch primes, English target descriptions). Each block contained 48 trials: 24 critical trials and 24 filler trials. Both blocks contained six critical trials in each of the four priming conditions. The order of the two blocks was counterbalanced across the 16 lists. Furthermore, the items in each block were swapped in half of the lists, so as to create a different trial order for half of the lists. Each block started with four filler trials.

Procedure and design. The procedure was identical to that of Experiments 1-3, except that the prime language was varied within the experiment. The experiment was split into two blocks: a within-language block and a between-languages block. The order was counterbalanced across participants. After the first block was completed, the confederate and the participant were notified that they had reached the second part of the experiment. A short instruction followed in which the experimenter explained that the language used by the confederate would switch either to English or to Dutch. After the break, the confederate again took the first turn in the dialogue. The experiment lasted about $30 \mathrm{~min}$.

To summarize, the design of this experiment was different from the previous experiments in the following ways: (a) The factor Object Repetition was varied within items; (b) the prime language was varied within participants; and (c) the extra factors Block Order and Trial Order were both manipulated between-participants and within-items. In other respects, the design stayed the same as the previous experiments.

\section{Results}

Across all conditions, 45 of the 1,536 target responses were Other responses $(2.9 \%)$. The remaining responses were classified either as AN- (1,472 of 1,536; $95.8 \%)$ or RC- (19 of 1,$536 ; 1.2 \%)$ responses. The response frequencies of Experiment 4 are reported in Table 3. The RC-proportions were calculated for all conditions and subjected to ANOVAs with Prime Type (AN- vs. RC-prime), Object Repetition (same-object vs. different-object), and Prime Language (Dutch vs. English) as within-participant and withinitem factors, and Block Order (between-languages vs. withinlanguage block first) as a between-participants and within-items factor.

All RC-responses (1.2\%) were produced when the prime language was English. Overall, we obtained a significant main effect of Prime Type, $F_{1}(1,30)=6.86, M S E=0.15, p<.05 ; F_{2}(1$, $44)=6.00, M S E=0.12, p<.05$, with participants producing more RC-target-responses following RC-primes than following 
Table 3

Response Frequencies of Experiment $4(L 1 \rightarrow L 2$ and $L 2 \rightarrow L 2)$

\begin{tabular}{|c|c|c|c|c|c|c|c|c|}
\hline \multirow[b]{3}{*}{ Block order } & \multirow[b]{3}{*}{ Prime language } & \multirow[b]{3}{*}{ Prime type } & \multicolumn{6}{|c|}{ Object type } \\
\hline & & & \multicolumn{3}{|c|}{ Repeated object } & \multicolumn{3}{|c|}{ Different object } \\
\hline & & & $\mathrm{AN}$ & $\mathrm{RC}$ & Other & AN & $\mathrm{RC}$ & Other \\
\hline \multirow[t]{4}{*}{$\mathrm{L} 2 \rightarrow \mathrm{L} 2$ first } & $\mathrm{L} 1 \rightarrow \mathrm{L} 2$ & $\mathrm{AN}$ & 95 & 0 & 1 & 93 & 0 & 3 \\
\hline & & $\mathrm{RC}$ & 92 & 0 & 4 & 93 & 0 & 3 \\
\hline & $\mathrm{L} 2 \rightarrow \mathrm{L} 2$ & AN & 93 & 0 & 3 & 94 & 0 & 2 \\
\hline & & $\mathrm{RC}$ & 80 & 13 & 3 & 88 & 3 & 5 \\
\hline \multirow[t]{4}{*}{$\mathrm{L} 1 \rightarrow \mathrm{L} 2$ first } & $\mathrm{L} 1 \rightarrow \mathrm{L} 2$ & AN & 89 & 0 & 7 & 92 & 0 & 4 \\
\hline & & $\mathrm{RC}$ & 91 & 0 & 5 & 93 & 1 & 2 \\
\hline & $\mathrm{L} 2 \rightarrow \mathrm{L} 2$ & AN & 96 & 0 & 0 & 95 & 0 & 1 \\
\hline & & $\mathrm{RC}$ & 93 & 2 & 1 & 95 & 0 & 1 \\
\hline
\end{tabular}

Note. $\mathrm{L} 1=$ native language; $\mathrm{L} 2=$ second language; $\mathrm{AN}=$ structure in which the adjective is placed before the noun; $\mathrm{RC}=$ structure in which the noun is followed by a relative clause containing the adjective.

AN-primes. However, this effect is due to the RC-responses in the within-language conditions only. Separate analyses for each prime language revealed that the effect of Prime Type was significant when the prime language was English (i.e., within-language), $F_{1}(1$, $30)=5.90, M S E=0.26, p<.05 ; F_{2}(1,47)=12.37, M S E=0.29$, $p<.005$; but not when the prime language was Dutch (i.e., between-languages), $F_{1}(1,30)=1.22, M S E=0.002, p>.10$; $F_{2}<1$.

Additionally, a further division between the levels of Block Order and Prime language shows that within-language priming only occurred when the within-language block was presented first, $F_{1}(1,15)=4.90, M S E=0.42, p<.05 ; F_{2}(1,47)=13.49$, $M S E=0.41, p<.005$. In this group, we found an $8.6 \%$ effect of Prime Type. When the within-language block was preceded by the between-languages block, no within-language priming was found, $F_{1}(1,15)=2.52, M S E=0.01, p>.10 ; F_{2}(1,47)=1.83, M S E=$ $0.013, p>.10$ : Only $1.0 \%$ more RC-responses were produced after RC-primes than after AN-primes. This results in an interaction between Prime Type and Block Order for the within-language block (near significant by participants), $F_{1}(1,30)=3.79, M S E=$ $0.17, p<.10 ; F_{2}(1,47)=9.64, M S E=0.14, p<.005$ : More within-language priming may have occurred when the withinlanguage block was presented first than when it was presented after the between-language block.

When the within-language block was presented first, the effect of Prime Type was much larger in the same-object condition $(14.0 \%)$ than in the different-object condition (3.3\%). Despite this lexical boost of $10.7 \%$, the interaction between Prime Structure and Object Repetition was not significant, $F_{1}(1,15)=2.55$, $M S E=0.17, p>.10 ; F_{2}(1,47)=2.67, M S E=0.07, p>.10$. No other effects were significant.

\section{Discussion}

The results of this experiment confirm that for Dutch-English bilinguals, syntactic priming of noun-phrase structure does not transfer between Dutch and English. There was a main effect of Prime Type, but it was due to effects in only one pair of conditions: There was an effect of syntactic priming only with withinlanguage primes, and only when the within-language block was presented first. Under these conditions, the effects that were found were similar to those in Experiment 2 for English primes: We found syntactic priming in both experiments and no reliable lexical boost of this effect.

The most important finding in this experiment is, of course, that no syntactic priming was obtained in the between-languages block. Moreover, the absence of RC-descriptions in the betweenlanguages block appeared to influence descriptions in the withinlanguage block. The proportion of RC-responses in the withinlanguage block dropped from $4.3 \%$ when this block was presented first to $0.5 \%$ when the between-languages block was presented first. This difference of $3.8 \%$ could be an effect of long-term priming. If the between-languages block was presented first, participants had encountered up to $72 \mathrm{AN}$-structures (24 prime sentences and up to 48 target sentences) and only 24 RC-structures, all of which were not in the target language and hence had a different word order, when they started with the within-language block. This predominance of $\mathrm{AN}$-structures in the between-language block may have boosted the accessibility of the AN-structure. Accordingly, the imbalance between the accessibility of both structures may have become insurmountable by the time the participants had to start with the within-language block. When the within-language block was presented first, the difference between the accessibility of both structures was smaller, and therefore the $\mathrm{RC}$-primes were able to influence the target responses.

\section{Experiment 5: Dutch (L1) to German (L2) Priming}

The absence of cross-linguistic syntactic priming between Dutch and English noun phrases seems to be a very robust finding. We tested cross-linguistic priming in three different experiments (Experiments 3a, 3b, and 4) and did not obtain significant crosslinguistic priming in any of them. This suggests that the use of RC-structures cannot be primed between Dutch and English. The results of Experiment 4 show that the absence of cross-linguistic priming for noun phrases can even influence the priming effects in a within-language priming experiment.

These results suggest that the absence of cross-linguistic priming is because relative clauses have different word orders in Dutch and English. However, it is conceivable that the lack of priming 
has some other explanation. Thus, cross-linguistic priming of noun-phrase structure might not occur (even though both withinlanguage priming of noun-phrase structure and other forms of cross-linguistic priming do occur). Hence it was important to test for cross-linguistic priming of noun phrases when word order was repeated. We therefore conducted a cross-linguistic syntactic priming experiment with Dutch-German bilinguals. Both the ANstructures and the RC-structures have the same word order in Dutch and German (see 10b-10c and 11b-11c). If the absence of cross-linguistic priming in Experiments 3-4 is the result of word order differences in Dutch and English RC-structures, we should obtain cross-linguistic priming between Dutch and German noun phrases. Because several studies of lexical priming have found stronger effects from L1 to L2 than from L2 to L1 (De Groot \& Nas, 1991; Gollan, Forster, \& Frost, 1997; Grainger \& FrenckMestre, 1998; Sánchez-Casas et al., 1992), we opted to prime from Dutch (L1) to German (L2).

\section{Method}

Participants. Twenty-eight 2nd year students studying German at Ghent University, the University of Antwerp, or the school for interpreters in Ghent or Antwerp (19 women and 9 men) participated in exchange for payment. All of them were native speakers of Dutch and had normal or corrected-to-normal vision. They all reported to have had at least 3 years of experience with German ( $M=9.1$ years). A female undergraduate student (with L1 Dutch and L2 German) acted as the confederate.

Materials. The materials were identical to those in Experiments $1-4$. The prime descriptions and the noun phrases that were used for the confederate's filler task were printed in Dutch (see Appendix B).

Procedure and design. The procedure and the design were almost identical to that of Experiments 1-3. In this experiment, the prime language was Dutch, and the target language was German. Hence, in the study session that preceded the experiment, every object was presented with its Dutch and its German name. If German synonyms or hyponyms were used to describe pictures in the same-object condition, the corresponding responses were counted as Other responses; when used in the different-object condition, such responses were counted as correct responses.

\section{Results}

Of the 1,344 target responses, 150 were Other responses $(11.2 \%)$. The remaining responses were classified either as AN$(1,105 ; 82.2 \%)$ or RC- $(89 ; 6.6 \%)$ responses (see Table 4 for the response frequencies in all conditions). ANOVAs were run on the proportions of RC-responses with Prime Type (AN-vs. RC-prime) as a within-participant and within-item factor and Object Repetition (same-object vs. different-object) as a within-participant and between-items factor. The mean proportion of RC-responses was larger after RC-primes (11.2\%) than after AN-primes (3.6\%), yielding a $7.6 \%$ effect of Prime Type, $F_{1}(1,27)=4.69, M S E=$ $0.78, p<.05 ; F_{2}(1,47)=36.73, M S E=0.29, p<.001 .{ }^{1}$ There was no main effect of Object Repetition (both $F \mathrm{~s}<1$ ) and no Prime Type $\times$ Object Repetition interaction (both $F_{\mathrm{S}}<1$ ). The effect of Prime Type was of a similar magnitude in the same-object (7.9\%) and the different-object conditions (7.3\%). Separate anal-
Table 4

Response Frequencies of Experiment 5 (L1 $\rightarrow$ L2)

\begin{tabular}{|c|c|c|c|c|c|c|}
\hline \multirow{3}{*}{$\begin{array}{l}\text { Prime } \\
\text { type }\end{array}$} & \multicolumn{6}{|c|}{ Object type } \\
\hline & \multicolumn{3}{|c|}{ Repeated object } & \multicolumn{3}{|c|}{ Different object } \\
\hline & AN & $\mathrm{RC}$ & Other & AN & $\mathrm{RC}$ & Other \\
\hline AN & 279 & 10 & 47 & 296 & 12 & 28 \\
\hline $\mathrm{RC}$ & 251 & 31 & 54 & 279 & 36 & 21 \\
\hline
\end{tabular}

Note. $\mathrm{L} 1=$ native language; $\mathrm{L} 2=$ second language; $\mathrm{AN}=$ structure in which the adjective is placed before the noun; $\mathrm{RC}=$ structure in which the noun is followed by a relative clause containing the adjective.

yses for each level of Object Repetition indicated that the effect of Prime Type was only near significant in the same-object conditions, $F_{1}(1,27)=3.09, M S E=0.44, p<.10 ; F_{2}(1,47)=12.78$, $M S E=0.64, p<.001$; but significant in the different-object conditions, $F_{1}(1,27)=4.54, M S E=0.35, p<.05 ; F_{2}(1,47)=$ 12.24, MSE $=0.42, p<.001$.

\section{Discussion}

The results of this experiment show cross-linguistic syntactic priming from Dutch (L1) to German (L2): More German RCdescriptions were produced after Dutch RC-descriptions than after Dutch AN-descriptions. This syntactic priming effect did not only occur when the head nouns were translation equivalents in prime and target descriptions but also when a different head noun was used. Thus, cross-linguistic priming of noun phrases does occur.

The effect was of a similar magnitude in the same-object and the different-object conditions and no translation-equivalent boost was observed. In contrast, Schoonbaert et al. (2007) did find a translation-equivalence boost for datives when priming from L1 to L2. In our experiment, the large number of Other responses in the same-object conditions may be partly responsible for the absence of a translation-equivalence boost. However, a more obvious explanation for the absence of a translation-equivalence boost in the present experiment is that the priming effects are rather small (maximum 8\%) and are thus not easily influenced.

The most important result is, however, that significant crosslinguistic priming can be obtained for noun phrases if these noun

\footnotetext{
${ }^{1}$ The effect of cross-linguistic priming was numerically smaller for students studying German at the school for interpreters $(3.4 \%)$ than for students studying Dutch and German literature and linguistics at the university (9.2\%). However, the interaction between Prime Type and Type of Education (interpreter vs. linguist) was not significant by participants, $F_{1}<1 ; F_{2}(1,36)=15.66, M S E=0.36, p<.001$. Furthermore, the analyses showed no difference in the percentages of Other responses that were produced by the linguistics students $(11.2 \%)$ and the interpreters $(12.1 \%), F_{1}<1 ; F_{2}(1,43)=2.46, M S E=0.72, p>.10$. As the majority of the Other responses were naming errors, this suggests that there is no difference between the levels of proficiency of the two groups. The small difference in the amount of cross-linguistic priming may be due to different emphases in the training program for linguists and interpreters. As interpreters are trained to translate under time pressure and between different languages, they might avoid the use of parallel sentence structures in different languages to lower the error risk.
} 
phrases have an identical word order in the languages under study (here: Dutch [L1] and German [L2]). This contrasts strikingly with the absence of cross-linguistic priming between Dutch and English when word order differs (Experiments 3-4).

\section{General Discussion}

In this study, we wanted to determine the conditions in which Dutch, English, and German noun phrases share a syntactic representation in the memory of Dutch-English and Dutch-German bilinguals. More specifically, we investigated the level of abstractness of these representations: Are they specified for language and for word order or is there a common, non-language-specific representation that is unspecified for word order? To this aim, we conducted five experiments that investigated syntactic priming of noun phrases in Dutch (L1: Experiment 1), in English (L2: Experiments 2 and 4), between English and Dutch (L2 $\rightarrow$ L1: Experiment 3a; L1 $\rightarrow$ L2: Experiments $3 \mathrm{~b}$ and 4), and between Dutch and German (L1 $\rightarrow$ L2: Experiment 5). Experiments 1, 2, and 4 showed that the structure of noun phrases can be primed in a within-language context: In both L1 and L2, significantly more $\mathrm{RC}$-structures were produced following RC-primes than after ANprimes. Hence, abstract syntactic representations of both nounphrase structures were accessed during the comprehension and the production of both Dutch and English noun phrases. However, cross-linguistic priming occurred only when prime and target phrases had an identical word order: Significant priming was found between Dutch and German (Experiment 5) but not between Dutch and English (Experiments 3a, 3b, and 4). These results suggest that Dutch RC-structures do not prime the use of English $\mathrm{RC}$-structures (and vice versa) because these structures do not share the same word order.

It is important to stress that previous studies (Hartsuiker et al., 2004; Loebell \& Bock, 2003; Meijer \& Fox Tree, 2003; Schoonbaert et al., 2007), including studies that tested Dutch-English bilinguals (Schoonbaert et al., 2007), also have provided strong evidence for cross-linguistic priming, specifically for structures that do have the same word order in both languages. The one experiment that did not find any cross-linguistic priming (Loebell \& Bock's, 2003, study with German and English transitives) used sentences that differed in word order between the languages. Consequently, the most likely explanation of the lack of crosslinguistic priming between Dutch and English noun phrases is that Dutch and English relative clauses differ in word order.

At first sight, this finding seems to contradict the results that were found by Desmet and Declercq (2006): They obtained crosslinguistic priming for relative clause attachments from Dutch to English, despite the word order differences in Dutch and English relative clauses. Participants produced more high-attachment relative clauses in English after Dutch primes that forced disambiguation toward high attachment (e.g., De politie ondervroeg de veroorzaakster van het ongeval die. .., in which the relative pronoun refers to the feminine noun "veroorzaakster") than after primes in which a low attachment was enforced (e.g., De politie ondervroeg de veroorzaakster van het ongeval dat. .., in which the relative pronoun refers to the neuter noun "ongeval"). However, their task and the syntactic choices were different from ours: In their study, a relative clause had to be produced to complete the target sentences (target sentence beginnings, such as "The farmer fed the calves of the cow that...," could only be completed by a relative clause), whereas in our study, a choice could be made between RC-structures and AN-structures for the description of a picture. In the former case, participants have to choose where to attach the relative clause, in the latter case, participants have to choose whether to produce a relative clause. Because the participants in the study by Desmet and Declercq were not free to choose whether to use an AN- or an RC-structure to complete the target sentences, the results of their study cannot inform us on the influence of word order differences in Dutch and English relative clauses on cross-linguistic syntactic priming of relative clauses.

Note that in all our cross-linguistic priming experiments, the AN-structures had the same word order, irrespective of whether the RC-structures had the same order. One might therefore expect cross-linguistic priming of the AN-structures in Experiments 3-4. However, the AN-structure is always so strongly preferred that there is little "room" for priming of the structure. As the ANstructures are much more frequently used than the RC-structures, the accessibility of AN-structures is so high that an increase in the accessibility of $\mathrm{AN}$-structures can no longer be reflected in the responses in the AN-conditions: In Experiment 4, the proportion of AN-responses was at ceiling $(100 \%)$ in all AN-conditions. In the same experiment, however, the AN-responses influenced the production of RC-responses: The predominance of AN-structures in the first block caused a steep drop in the proportion of RCresponses in the second block. This effect of cumulative long-term priming suggests that the accessibility of the $\mathrm{AN}$-structures was further increased during the experiment and that AN-structures are primed between languages.

It is interesting to see that the occurrence of cross-linguistic priming for noun phrases is conditional on the match in word order after the decision about whether to start with the noun or the adjective. In other words, the internal structure of the relative clause influences the syntactic choice that has to be made earlier on in the formulation of the sentence. This finding is compatible to what Griffin and Weinstein-Tull (2003) found for the priming of infinitive complements. The finite complements of object-raising verbs (e.g., John believed that Mary was nice) were less often paraphrased as infinitive complements (e.g., John believed Mary to be nice) after primes with identical constituent orders as objectraising infinitives but an additional conceptual role (e.g., John persuaded Mary to be nice, in which Mary is not only the direct object of the main verb but also the argument of nice) than after object-raising infinitives. The decision to place either that or Mary after the verb is conditional on the number of conceptual roles that are assigned to Mary. This suggests that the internal structure of constituents can influence structural priming.

One further aspect of our data merits discussion. Our experiments varied whether the head noun was identical between prime and target. Previous within-language studies have shown that repetition of the head verb in dative sentences (e.g., Branigan et al., 2000; Cleland \& Pickering, 2006; Corley \& Scheepers, 2002; Pickering \& Branigan, 1998) or head noun in noun phrases (Cleland \& Pickering, 2003) resulted in a considerably larger priming effect (the lexical boost). Indeed, Schoonbaert et al. (2007) showed that with datives, verb repetition increased within-language priming effects both within L1 and L2. In contrast, the current study found a reliable boost within L1 (Experiment 1) but inconsistent results within L2 (no difference in Experiment 2; a nonsignificant 
trend of $10 \%$ in the within-language condition of Experiment 4). In cross-linguistic priming conditions, Schoonbaert et al. also found a translation-equivalence boost when priming from L1 to L2 but not when priming from L2 to L1. The translation-equivalence boost never occurred in the current study (Experiments 3-5). In fact, the translation-equivalence boost could only occur between Dutch and German, as we obtained no significant priming between Dutch and English.

The fragility of the lexical boost in within-language priming in L2 and the absence of a translation-equivalence boost in crosslinguistic priming from L1 to L2 may reflect the relatively small priming effects in our experiments in comparison with earlier studies of the lexical boost (Branigan et al., 2000: 55\% in the same-verb condition, $26 \%$ in the different-verb condition; Cleland \& Pickering's, 2003, Experiment 1: 27\% in the same-noun condition, $12 \%$ in the different-noun condition; Cleland \& Pickering, 2006: $34 \%$ in the same-verb condition, $13 \%$ in the different-verb condition; Pickering \& Branigan, 1998: 20\% in the same-verb condition, $5 \%$ in the different-verb condition). Furthermore, the lexical boost that is caused by the repetition of verbs (Branigan et al., 2000: 29\% lexical boost; Schoonbaert et al.'s, 2007, Experiment 3: $29 \%$ lexical boost) seems to be larger than the boost that is obtained by repeating the head noun in prime and target constructions (Cleland \& Pickering, 2003: 15\% lexical boost; Experiment 1 in this study: $8 \%$ lexical boost). This difference in the magnitude of the lexical boost could explain why the lexical boost for verbs survives when the target language is not L1, whereas the lexical boost for nouns does not.

We now turn to the theoretical implications of our claim that word order needs to be similar before a construction is shared between the different languages of a bilingual speaker. In the introduction, we discussed two models of syntax production that aimed to explain word order effects in syntactic priming within languages: a one-stage account (Pickering et al., 2002) and a two-stage account (Hartsuiker et al., 1999; Hartsuiker \& Westenberg, 2000). The absence of RC-priming between Dutch and English in this study is consistent with the one-stage account of the formulation of constituent structure advocated by Pickering et al. (2002). On this account, a fully specified constituent structure is constructed directly from the functional level (specified in terms of grammatical roles, such as subject and object; see Bock \& Levelt, 1994). As there is no separate level that specifies the word order of the constituent structures, the syntactic representations necessarily incorporate information about word order. Word order forms part of constituent structure; hence, structures with differing word orders are represented separately, even though these structures might have identical hierarchical relations between constituents. In accord with this account, Pickering et al. found no syntactic priming between shifted datives (The captain gave to the old sailor the spare lifejacket) and PO datives with the same hierarchical relations (The captain gave the spare lifejacket to the old sailor). Specifically, they argued against a two-stage account in which people initially construct a hierarchical representation that is not specified for word order and then convert it to a fully specified representation following a process of linearization. Such an account would incorrectly predict priming between shifted datives and PO datives because they share a level of representation in which hierarchical (or dominance) relations are specified.
Recently, Haskell and MacDonald (2005) provided additional evidence against two-stage models of sentence production. They found proximity effects in the production of subject-verb agreement following disjunctive noun phrases (e.g., the shirt or the socks). Participants most often inflected the verb to agree with the nearer noun, whether this noun was singular or plural, and whether the verb followed or preceded the disjunction. They interpreted this influence of linear proximity on agreement as evidence for a one-stage account (in which agreement is computed over a linearly specified representation of constituent structure).

Our results can be explained by the one-stage account (Pickering et al., 2002). Across our experiments, the prime expressions had three different word orders: determiner, adjective, noun (for AN-structures); determiner, noun, relative pronoun, adjective, verb (for Dutch and German RC-structures); and determiner, noun, relative pronoun, verb, adjective (for English RC-structures). The two-stage account predicts that people construct a level of representation specified for hierarchical structure but not linear order, and so we should have found priming between the Dutch and English RC-structures, as these structures share dominance relations: The only difference between the structures is the position of the verb and the modifier in the relative clause. According to the one-stage account, however, Dutch-English bilinguals have (at least) three different word-order specific representations for noun phrases: a representation for the $\mathrm{AN}$-structure and two separate representations for the RC-structures. Because a different representation is accessed during the processing and the production of Dutch and English RC-structures, no cross-linguistic priming is observed. Note that our results could also be explained by recent implicit learning models (e.g., Chang, Dell, Bock, \& Griffin, 2000; Dell, Chang \& Griffin, 1999), as they also suggest that syntax is formulated in one stage.

In Figure 3 we present a model for the comprehension and the production of complex noun phrases in Dutch-English-German trilinguals, on the basis of Hartsuiker et al. (2004) and derived from Pickering and Branigan (1998) and Cleland and Pickering (2003). This model features a shared representation for Dutch, German, and English AN-structures that is connected to the lemmas of Dutch, German, and English nouns. It includes two representations for RC-structures: The node (RC-verb-final) is connected to the lemmas of Dutch and German words; the node (RC-modifier-final) is connected to the lemmas of English words. The lemmas, in their turn, are tagged for their language by being linked to a "Dutch," "English," or "German" language node. The lemmas of translation-equivalent words in Dutch, English, and German are linked to a shared semantic node, and all noun lemmas are linked to the same categorical node "noun." A model for Dutch-English bilinguals would be similar, except that it would contain no German lemmas and no German language node; a model for Dutch-German bilinguals would contain no English lemmas, no English language node, and no RC-modifier-final node.

Following Schoonbaert et al. (2007), the links between the Dutch (L1) lexical representations and their concepts are stronger than both the English (L2) and the German (L2) lexical representations and their concepts. Schoonbaert et al. added this feature to their model to accommodate their finding that the translationequivalence boost occurred when priming from L1 to L2 but not 


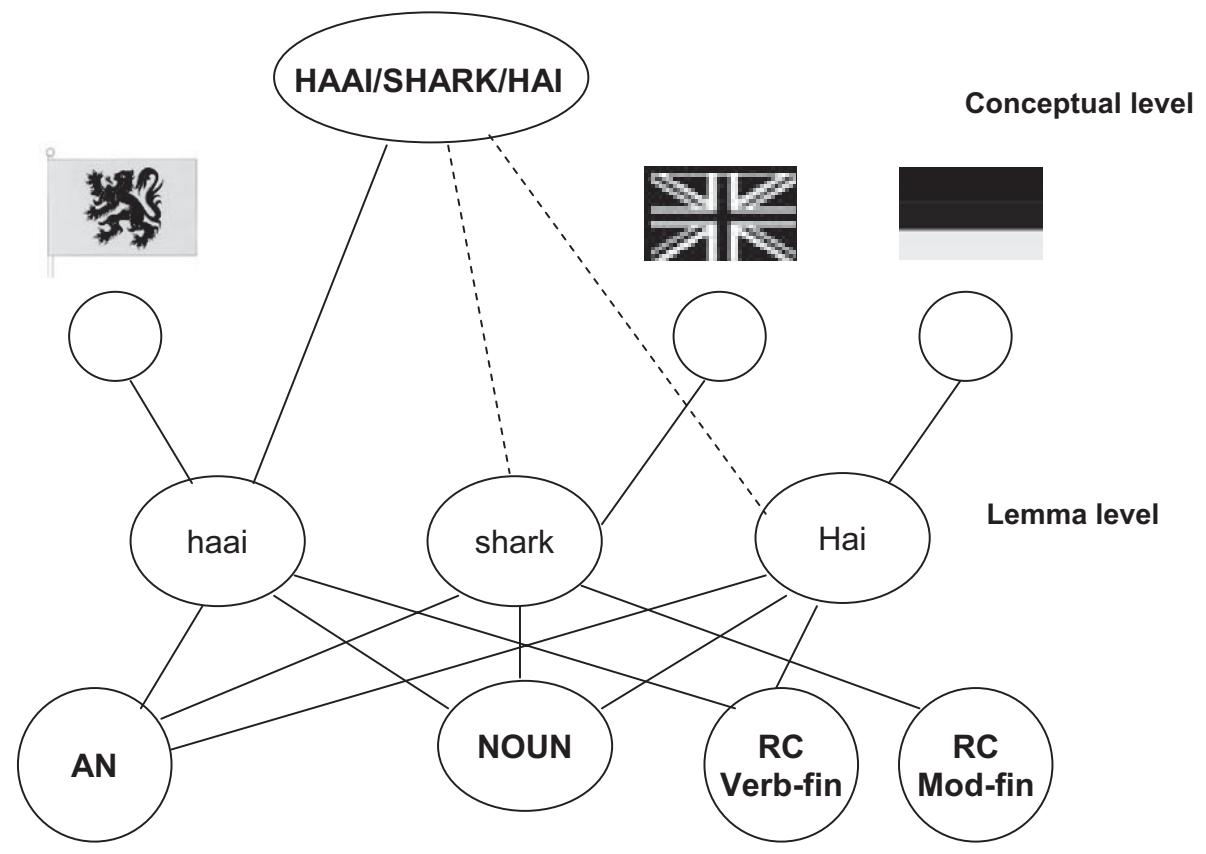

Figure 3. Model for the representation of noun-phrase structure in Dutch-English-German trilinguals (adapted from Schoonbaert et al., 2007). In this integrated network (featuring a shared lexicon and shared lexical representations), the lemma representations of Dutch (haai), English (shark), and German (Hai) nouns are linked to one conceptual node at the conceptual level, to one category node (Noun), and to one language node (represented by a Flemish, a British, and a German flag). Stronger connections between different nodes (resulting in more spreading activation) are indicated by full lines; weaker connections between nodes are indicated by dotted lines. All lemma representations are connected with the combinatorial node for the structure in which the adjective is placed before the noun (the AN-structure). Dutch and German lemmas are linked to the RC-verbfinal node (RC Verb-fin); English lemmas are linked to the RC-modifier-final node (RC Mod-fin). RC = structure in which the noun is followed by a relative clause containing the adjective.

when priming from L2 to L1, because the L2 lemmas are not or only weakly activated during the selection of L1 target words.

The combinatorial nodes in our model are not language specific: The RC-verb-final node is shared for Dutch and German nouns. Likewise, the RC-modifier-final node could be linked to both English and French nouns (as French relative clauses have the same word order as English relative clauses). Consequently, our model predicts cross-linguistic syntactic priming between relative clauses that have the same word order in two given languages (e.g., between Dutch and German, between English and French). In general, it predicts cross-linguistic priming for any related syntactic structures that have the same word order in the languages under study.

In conclusion, our study showed syntactic priming of nounphrase structures (AN- and RC-structures) within the first and the second language of Dutch-English bilinguals. In spite of significant within-language priming, no cross-linguistic priming was obtained between Dutch and English RC-structures. However, significant cross-linguistic priming was found between Dutch and German RC-structures. Given the data of Experiment 5 and given the strong evidence for cross-linguistic priming when word order is repeated (Hartsuiker et al., 2004; Loebell \& Bock, 2003; Meijer $\&$ Fox Tree, 2003; Schoonbaert et al., 2007), the absence of syntactic priming between Dutch and English noun phrases can be ascribed to the different word order of Dutch and English relative clauses. As these syntactic structures have different word orders, they do not share a syntactic representation. In contrast, because Dutch and German relative clauses have the same word order, they do share a syntactic representation.

\section{References}

Arai, M., Van Gompel, R. P. G., \& Scheepers, C. (2007). Priming ditransitive structures in comprehension. Cognitive Psychology, 54, 218-250.

Bock, J. K. (1986). Syntactic persistence in language production. Cognitive Psychology, 18, 355-387.

Bock, J. K. (1989). Closed-class immanence in sentence production. Cognition, 31, 163-186.

Bock, J. K., \& Griffin, Z. M. (2000). The persistence of structural priming: Transient activation or implicit learning? Journal of Experimental Psychology: General, 129, 177-192.

Bock, J. K., \& Levelt, W. J. (1994). Language production: Grammatical encoding. In M. A. Gernsbacher (Ed.), Handbook of psycholinguistics (pp. 945-984). San Diego, CA: Academic Press.

Bock, J. K., \& Loebell, H. (1990). Framing sentences. Cognition, 35, 1-39.

Branigan, H. P., Pickering, M. J., \& Cleland, A. A. (2000). Syntactic co-ordination in dialogue. Cognition, 75, B13-B25.

Branigan, H. P., Pickering, M. J., \& McLean, J. F. (2005). Priming prepositional-phrase attachment during language comprehension. Journal of Experimental Psychology: Learning, Memory, and Cognition, 31, $468-481$.

Chang, F., Dell, G. S., Bock, K., \& Griffin, Z. M. (2000). Structural 
priming as implicit learning: Comparison of models of sentence production. Journal of Psycholinguistic Research, 29, 217-229.

Cleland, A. A., \& Pickering, M. J. (2003). The use of lexical and syntactic information in language production: Evidence from the priming of noun-phrase structure. Journal of Memory and Language, 49, 214-230.

Cleland, A. A., \& Pickering, M. J. (2006). Do writing and speaking employ the same syntactic representations? Journal of Memory and Language, $54,185-198$.

Corley, M., \& Scheepers, C. (2002). Syntactic priming in English sentence production: Categorical and latency evidence from an Internet-based study. Psychonomic Bulletin \& Review, 9, 126-131.

De Groot, A. M. B., \& Nas, G. L. (1991). Lexical representation of cognates and noncognates in compound bilinguals. Journal of Memory and Language, 30, 90-123.

Dell, G. S., Chang, F., \& Griffin, Z. M. (1999). Connectionist models of language production: Lexical access and grammatical encoding. Cognitive Science, 23, 517-542.

De Smedt, K. J. (1990). IPF: An incremental parallel formulator. In R. Dale, C. Mellish, \& M. Zock (Eds.), Current research in natural language generation (pp. 167-192). London: Academic Press.

Desmet, T., \& Declercq, M. (2006). Cross-linguistic priming of syntactic hierarchical configuration information. Journal of Memory and Language, 54, 610-632.

Dijkstra, T., Van Heuven, W., \& Grainger, J. (1998). Simulating crosslanguage competition with the Bilingual Interactive Activation model. Psychologica Belgica, 38, 177-196.

Ferreira, V. S. (1996). Is it better to give than to donate? Syntactic flexibility in language production. Journal of Memory and Language, $35,724-755$.

Ferreira, V. S. (2003). The persistence of optional complementizer production: Why saying "that" is not saying "that" at all. Journal of Memory and Language, 48, 379-398.

Ferreira, V. S., \& Bock, K. (2006). The functions of structural priming. Language and Cognitive Processes, 21, 1011-1029.

Fox Tree, J. E., \& Meijer, P. J. A. (1999). Building syntactic structure in speaking. Journal of Psycholinguistic Research, 28, 71-92.

Gollan, T. H., Forster, K. I., \& Frost, R. (1997). Translation priming with different scripts: Masked priming with cognates and noncognates in Hebrew-English bilinguals. Journal of Experimental Psychology: Learning, Memory, and Cognition, 23, 1122-1139.

Grainger, J., \& Frenck-Mestre, C. (1998). Masked priming by translation equivalents in proficient bilinguals. Language and Cognitive Processes, $13,601-623$.

Greenberg, J. H. (1963). Some universals of grammar with particular reference to the order of meaningful elements. In J. H. Greenberg (Ed.), Universals of language (pp. 73-113). Cambridge, MA: MIT Press.

Griffin, Z. M., \& Weinstein-Tull, J. (2003). Conceptual structure modulates structural priming in the production of complex sentences. Journal of Memory and Language, 49, 537-555.

Hartsuiker, R. J., \& Kolk, H. H. J. (1998a). Syntactic facilitation in agrammatic sentence production. Brain and Language, 62, 221-254.

Hartsuiker, R. J., \& Kolk, H. H. J. (1998b). Syntactic persistence in Dutch. Language and Speech, 41, 143-184.

Hartsuiker, R. J., Kolk, H. H. J., \& Huiskamp, P. (1999). Priming word order in sentence production. Quarterly Journal of Experimental Psychology: Human Experimental Psychology, 52(A), 129-147.
Hartsuiker, R. J., Pickering, M. J., \& Veltkamp, E. (2004). Is syntax separate or shared between languages? Cross-linguistic syntactic priming in Spanish-English bilinguals. Psychological Science, 15, 409-414.

Hartsuiker, R. J., \& Westenberg, C. (2000). Word order priming in written and spoken sentence production. Cognition, 75, B27-B39.

Haskell, T. R., \& MacDonald, M. C. (2005). Constituent structure and linear order in language production: Evidence from subject-verb agreement. Journal of Experimental Psychology: Learning, Memory, and Cognition, 31, 891-904.

Kashak, M. P., Loney, R. A., \& Borregine, K. L. (2006). Recent experience affects the strength of structural priming. Cognition, 99, B73-B82.

Kempen, G., \& Hoenkamp, E. (1987). An incremental procedural grammar for sentence formulation. Cognitive Science, 11, 201-258.

Lemhöfer, K., \& Dijkstra, T. (2004). Recognizing cognates and interlingual homographs: Effects of code similarity in language-specific and generalized lexical decision. Memory \& Cognition, 32, 533-550.

Lemhöfer, K., Dijkstra, T., \& Michel, M. C. (2004). Three languages, one ECHO: Cognate effects in trilingual word recognition. Language and Cognitive Processes, 19, 585-611.

Loebell, H., \& Bock, K. (2003). Structural priming across languages. Linguistics, 41, 791-824.

Meijer, P. J. A., \& Fox Tree, J. E. (2003). Building syntactic structures in speaking: A bilingual exploration. Experimental Psychology, 50, 184 195.

Noppeney, U., \& Price, C. J. (2004). An fMRI study of syntactic adaptation. Journal of Cognitive Neuroscience, 16, 702-713.

Pickering, M. J., \& Branigan, H. P. (1998). The representation of verbs: Evidence from syntactic priming in language production. Journal of Memory and Language, 39, 633-651.

Pickering, M. J., Branigan, H. P., \& McLean, J. F. (2002). Constituent structure is formulated in one stage. Journal of Memory and Language, 46, 586-605.

Pickering, M. J., \& Garrod, S. (2004). Toward a mechanistic psychology of dialogue. Behavioral and Brain Sciences, 27, 169-225.

Potter, M. C., \& Lombardi, L. (1998). Syntactic priming in immediate recall of sentences. Journal of Memory and Language, 38, 265-282.

Salamoura, A., \& Williams, J. N. (2006). Lexical activation of crosslanguage syntactic priming. Bilingualism: Language and Cognition, 9, 299-307.

Sánchez-Casas, R. M., Davis, C. W., \& Garcia-Albea, J. E. (1992). Bilingual lexical processing: Exploring the cognate/non-cognate distinction. European Journal of Cognitive Psychology, 4, 293-310.

Scheepers, C. (2003). Syntactic priming of relative clause attachments: Persistence of structural configuration in sentence production. Cognition, 89, 179-205.

Schoonbaert, S., Hartsuiker, R. J., \& Pickering, M. J. (2007). The representation of lexical and syntactic information in bilinguals: Evidence from syntactic priming. Journal of Memory and Language, 56, 153-171.

Van Hell, J. G., \& De Groot, A. M. B. (1998). Conceptual representation in bilingual memory: Effects of concreteness and cognate status in word association. Bilingualism: Language and Cognition, 1, 193-211.

Van Hell, J. G., \& Dijkstra, A. (2002). Foreign language knowledge can influence native language performance in exclusively native contexts. Psychonomic Bulletin \& Review, 9, 780-789. 
Appendix A

Items for Experiments 1-4

On the first line, the RC- and AN-primes are shown in Dutch (these primes were used in Experiments 1, 3, and 4) and on the second line in English (these primes were used in Experiments 2, 3, and 4). On the third line the unrelated and related target pictures are described. In Experiment 4, only the related target pictures were used, and the objects on the unrelated target pictures were used to construct the unrelated prime descriptions.

1. de platenspeler die rood is/de rode platenspeler the record player that is red/the red record player red pineapple/red record player

2. de pan die blauw is/de blauwe pan

the pan that is blue/the blue pan

green star/green pan

3. de hand die geel is/de gele hand the hand that is yellow/the yellow hand red hat/red hand

4. de clown die groen is/de groene clown

the clown that is green/the green clown yellow bottle/yellow clown

5. de muur die geel is/de gele muur the wall that is yellow/the yellow wall red ax/red wall

6. de man die geel is/de gele man the man that is yellow/the yellow man blue owl/blue man

7. de baby die blauw is/de blauwe baby the baby that is blue/the blue baby red penguin/red baby

8. de arm die rood is/de rode arm the arm that is red/the red arm yellow comb/yellow arm 9. de cactus die rood is/de rode cactus the cactus that is red/the red cactus green watering can/green cactus 10. de pizza die rood is/de rode pizza the pizza that is red/the red pizza green couch/green pizza

11. de giraffe die blauw is/de blauwe giraffe the giraffe that is blue/the blue giraffe yellow tweezers/yellow giraffe

12. de wortel die groen is/de groene wortel the carrot that is green/the green carrot red kite/red carrot

13. de heks die rood is/de rode heks the witch that is red/the red witch yellow peacock/yellow witch

14. de zweep die rood is/de rode zweep the whip that is red/the red whip

yellow train/yellow whip

15. de ananas die rood is/de rode ananas the pineapple that is red/the red pineapple green mushroom/green pineapple 16. de tank die geel is/de gele tank the tank that is yellow/the yellow tank blue scarf/blue tank

17. de schildpad die rood is/de rode schildpad the turtle that is red/the red turtle yellow hose/yellow turtle 18. de ring die blauw is/de blauwe ring the ring that is blue/the blue ring green flower/green ring 19. de lamp die rood is/de rode lamp the lamp that is red/the red lamp yellow bow/yellow lamp 20. de mixer die groen is/de groene mixer the mixer that is green/the green mixer blue wing/blue mixer

21. de bliksem die geel is/de gele bliksem the lightning that is yellow/the yellow lightning green strawberry/green lightning

22. de paraplu die rood is/de rode paraplu the umbrella that is red/the red umbrella blue telephone/blue umbrella 23. de tent die groen is/de groene tent the tent that is green/the green tent yellow spider/yellow tent 24. de riem die geel is/de gele riem the belt that is yellow/the yellow belt red boat/red belt

25. de helicopter die blauw is/de blauwe helicopter the helicopter that is blue/the blue helicopter green wallet/green helicopter

26. de eskimo die groen is/de groene eskimo the Eskimo that is green/the green Eskimo blue painting/blue Eskimo

27. de eekhoorn die geel is/de gele eekhoorn the squirrel that is yellow/the yellow squirrel red glove/red squirrel

28. de ezel die rood is/de rode ezel the donkey that is red/the red donkey blue car/blue donkey 29. de harp die groen is/de groene harp the harp that is green/the green harp red crown/red harp 30. de eend die groen is/de groene eend the duck that is green/the green duck blue zipper/blue duck

31. de haai die geel is/de gele haai the shark that is yellow/the yellow shark red pear/red shark

32. de zebra die rood is/de rode zebra

the zebra that is red/the red zebra green trumpet/green zebra 33. de robot die groen is/de groene robot the robot that is green/the green robot blue butterfly/blue robot

34. de schommelstoel die groen is/de groene schommelstoel 
the rocking chair that is green/the green rocking chair yellow mailbox/yellow rocking chair 35. de piano die rood is/de rode piano the piano that is red/the red piano blue medal/blue piano 36. de doos die groen is/de groene doos the box that is green/the green box yellow feather/yellow box

37. de stoel die blauw is/de blauwe stoel the chair that is blue/the blue chair red bicycle/red chair 38. de barbecue die blauw is/de blauwe barbecue the barbecue that is blue/the blue barbecue green lipstick/green barbecue 39. de spiegel die blauw is/de blauwe spiegel the mirror that is blue/the blue mirror red seal/red mirror 40. de worm die geel is/de gele worm the worm that is yellow/the yellow worm blue cake/blue worm 41. de bus die blauw is/de blauwe bus the bus that is blue/the blue bus green arrow/green bus

42. de citroen die groen is/de groene citroen the lemon that is green/the green lemon yellow magnet/yellow lemon 43. de wolk die blauw is/de blauwe wolk the cloud that is blue/the blue cloud red pliers/red cloud 44. de staart die blauw is/de blauwe staart the tail that is blue/the blue tail green lobster/green tail 45. de ladder die blauw is/de blauwe ladder the ladder that is blue/the blue ladder green apple/green ladder 46. de boom die geel is/de gele boom the tree that is yellow/the yellow tree blue ant/blue tree

47. de schoorsteen die groen is/de groene schoorsteen the chimney that is green/the green chimney blue palm tree/blue chimney 48. de steen die geel is/de gele steen the rock that is yellow/the yellow rock green pants/green rock

\section{Appendix B}

\section{Items for Experiment 5}

On the first line, the related $\mathrm{RC}$ - and $\mathrm{AN}$-primes are shown in Dutch (followed by their English translation); on the second line, the unrelated RC- and AN-primes are shown in Dutch (followed by their English translation); on the third line, the targets are shown in German (followed by their English translation).

1. de platenspeler die geel is/de gele platenspeler [yellow record player]

de gele ananas/de gele ananas [yellow pineapple]

der Schallplattenspieler [the record player]

2. de pan die groen is/de groene pan [green pan]

de ster die groen is/de groene ster [green star]

die Pfanne [the pan]

3. de hand die rood is/de rode hand [red hand]

de pet die rood is/de rode pet [red hat]

die Hand [the hand]

4. de clown die geel is/de gele clown [yellow clown]

de fles die geel is/de gele fles [yellow bottle]

der Clown [the clown]

5. de muur die rood is/de rode muur [red wall]

de bijl die rood is/de rode bijl [red axe]

die Mauer [the wall]

6. de man die blauw is/de blauwe man [blue man]

de uil die blauw is/de blauwe uil [blue owl]

der Mann [the man]

7. de baby die rood is/de rode baby [red baby]

de penguin die rood is/de rode pinguin [red penguin]

das Baby [the baby]

8. de arm die geel is/de gele arm [yellow arm]

de kam die geel is/de gele kam [yellow comb] der Arm [the arm]

9. de cactus die groen is/de groene cactus [green cactus] de gieter die groen is/de groene gieter [green watering can] der Kaktus [the cactus]

10. de pizza die groen is/de groene pizza [green pizza]

de zetel die groen is/de groene zetel [green couch] die Pizza [the pizza]

11. de giraffe die geel is/de gele giraffe [yellow giraffe] de pincet die geel is/de gele pincet [yellow tweezers] die Giraffe [the giraffe]

12. de wortel die rood is/de rode wortel [red carrot] de vlieger die rood is/de rode vlieger [red kite] die Karotte [the carrot]

13. de heks die geel is/de gele heks [yellow witch] de pauw die geel is/de gele pauw [yellow peacock] die Hexe [the witch]

14. de zweep die geel is/de gele zweep [yellow whip] de trein die geel is/de gele trein [yellow train] die Peitsche [the whip]

15. de ananas die groen is/de groene ananas [green pineapple] de paddestoel die groen is/de groene paddestoel [green mushroom]

die Ananas [the pineapple]

16. de tank die blauw is/de blauwe tank [blue tank]

de sjaal die blauw is/de blauwe sjaal [blue scarf]

der Panzer [the tank]

17. de schildpad die geel is/de gele schildpad [yellow turtle] die tuinslang die geel is/de gele tuinslang [yellow hose] die Schildkröte [the turtle] 
18. de ring die groen is/de groene ring [green ring] de bloem die groen is/de groene bloem [green flower] der Ring [the ring]

19. de lamp die geel is/de gele lamp [yellow lamp] de strik die geel is/de gele strik [yellow bow]

die Lampe [the lamp]

20. de mixer die blauw is/de blauwe mixer [blue mixer] de vleugel die blauw is/de blauwe vleugel [blue wing] der Mixer [the mixer]

21. de bliksem die groen is/de groene bliksem [green lightning] de aardbei die groen is/de groene aardbei [green strawberry] der Blitz [the lightning]

22. de paraplu die blauw is/de blauwe paraplu [blue umbrella] de telefoon die blauw is/de blauwe telefoon [blue telephone]

der Regenschirm [the umbrella]

23. de tent die geel is/de gele tent [yellow tent]

de spin die geel is/de gele spin [yellow spider]

das Zelt [the tent]

24. de riem die rood is/de rode riem [red belt]

de boot die rood is/de rode boot [red boat]

der Guertel [the belt]

25. de helicopter die groen is/de groene helicopter [green helicopter]

de portefeuille die groen is/de groene portefeuille [green wallet] der Hubschrauber [the helicopter]

26. de eskimo die blauw is/de blauwe eskimo [blue Eskimo] het schilderij dat blauw is/het blauwe schilderij [blue painting] der Eskimo [the Eskimo]

27. de eekhoorn die rood is/de rode eekhoorn [red squirrel] de handschoen die rood is/de rode handschoen [red glove] das Eichhörnchen [the squirrel]

28. de ezel die blauw is/de blauwe ezel [blue donkey]

de auto die blauw is/de blauwe auto [blue car]

der Esel [the donkey]

29. de harp die rood is/de rode harp [red harp]

de kroon die rood is/de rode kroon [red crown]

die Harfe [the harp]

30. de eend die blauw is/de blauwe eend [blue duck]

de rits die blauw is/de blauwe rits [blue zipper]

die Ente [the duck]

31. de haai die rood is/de rode haai [red shark]

de peer die rood is/de rode peer [red pear]

der Hai [the shark]

32. de zebra die groen is/de groene zebra [green zebra] de trompet die groen is/de groene trompet [green trumpet] das Zebra [the zebra]

33. de robot die blauw is/de blauwe robot [blue robot] de vlinder die blauw is/de blauwe vlinder [blue butterfly] der Roboter [the robot]

34. de schommelstoel die geel is/de gele schommelstoel [yellow rocking chair] de brievenbus die geel is/de gele brievenbus [yellow mailbox] der Schaukelstuhl [the rocking chair]

35. de piano die blauw is/de blauwe piano [blue piano] de medaille die blauw is/de blauwe medaille [blue medal] das Klavier [the piano]

36. de doos die geel is/de gele doos [yellow box] de veer die geel is/de gele veer [yellow feather] der Karton [the box]

37. de stoel die rood is/de rode stoel [red chair] de fiets die rood is/de rode fiets [red bicycle] der Stuhl [the chair]

38. de barbecue die groen is/de groene barbecue [green barbecue]

de lippenstift die groen is/de groene lippenstift [green lipstick] der Grill [the barbecue]

39. de spiegel die rood is/de rode spiegel [red mirror]

de zeehond die rood is/de rode zeehond [red seal]

der Spiegel [the mirror]

40. de worm die blauw is/de blauwe worm [blue worm]

de taart die blauw is/de blauwe taart [blue cake]

der Wurm [the worm]

41. de bus die groen is/de groene bus [green bus]

de pijl die groen is/de groene pijl [green arrow]

der Bus [the bus]

42. de citroen die geel is/de gele citroen [yellow lemon]

de magnet die geel is/de gele magneet [yellow magnet]

die Zitrone [the lemon]

43. de wolk die rood is/de rode wolk [red cloud]

de tang die rood is/de rode tang [red pliers]

die Wolke [the cloud]

44. de staart die groen is/de groene staart [green tail]

de kreeft die groen is/de groene kreeft [green lobster]

der Schwanz [the tail]

45. de ladder die groen is/de groene ladder [green ladder]

de appel die groen is/de groene appel [green apple]

die Leiter [the ladder]

46. de boom die blauw is/de blauwe boom [blue tree]

de mier die blauw is/de blauwe mier [blue ant]

der Baum [the tree]

47. de schoorsteen die blauw is/de blauwe schoorsteen [blue chimney]

de palmboom die blauw is/de blauwe palmboom [blue palm tree]

der Schornstein [the chimney]

48. de steen die groen is/de groene steen [green rock]

de broek die groen is/de groene broek [green pants]

der Stein [the rock]

Received February 2, 2006

Revision received June 5, 2007

Accepted June 7, 2007 